\title{
Preparation and characterisation of high- density ionic liquids incorporating halobismuthate anions
}

Article

Accepted Version

Cousens, N. E. A., Taylor Kearney, L. J., Clough, M. T., Lovelock, K. R. J., Palgrave, R. G. and Perkin, S. (2014) Preparation and characterisation of high-density ionic liquids incorporating halobismuthate anions. Dalton Transactions, 43 (28). pp. 10910-10919. ISSN 1364-5447 doi:

https://doi.org/10.1039/c4dt00755g Available at https://centaur.reading.ac.uk/76262/

It is advisable to refer to the publisher's version if you intend to cite from the work. See Guidance on citing.

Published version at: http://dx.doi.org/10.1039/c4dt00755g

To link to this article DOI: http://dx.doi.org/10.1039/c4dt00755g

Publisher: Royal Society of Chemistry

All outputs in CentAUR are protected by Intellectual Property Rights law, including copyright law. Copyright and IPR is retained by the creators or other copyright holders. Terms and conditions for use of this material are defined in the End User Agreement. 


\section{CentAUR}

Central Archive at the University of Reading

Reading's research outputs online 


\section{Dalton
Transactions}

\section{Preparation and Characterisation of High-Density Ionic Liquids Incorporating Halobismuthate Anions}

\begin{tabular}{|r|l|}
\hline Journal: & Dalton Transactions \\
\hline Manuscript ID: & DT-ART-03-2014-000755.R1 \\
\hline Daticle Type: & Paper \\
\hline Complete List of Authors: & $\begin{array}{l}\text { Perkin, Susan; University of Oxford, Department of Chemistry } \\
\text { Cousens, Nico; Oxford University, Chemistry } \\
\text { Kearney, Leah; Oxford University, Chemistry } \\
\text { Clough, Matthew; Imperial College, London } \\
\text { Lovelock, Kevin; Imperial College London, Chemistry } \\
\text { Palgrave, Robert; UCL, Department of Chemistry }\end{array}$ \\
\hline
\end{tabular}

\section{SCHOLARONE ${ }^{\text {Tw }}$ \\ Manuscripts}


Preparation and Characterisation of High-Density lonic Liquids Incorporating Halobismuthate Anions

Nico E. A. Cousens ${ }^{\mathrm{a}}$, Leah J. Taylor Kearney ${ }^{\mathrm{a}}{ }^{\text {, }}$ Matthew T. Clough ${ }^{\mathrm{b}}$, Kevin R. J. Lovelock ${ }^{\mathrm{b}}$, Robert G. Palgrave ${ }^{c}$, Susan Perkin*a

\section{Graphical Abstract}

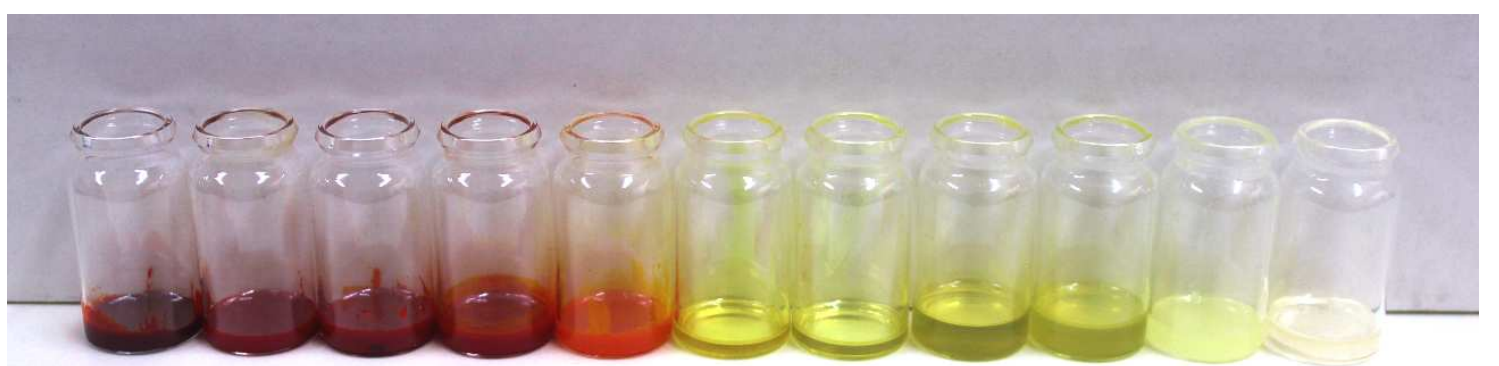

1-butyl-3-methylimidazolium tetrahalobismuthates. Chlorobismuthates are colourless. Upon substitution of chloride for bromide or iodide the liquids become progressively more yellow or red. 


\section{Preparation and Characterisation of High-Density Ionic Liquids Incorporating Halobismuthate Anions}

Nico E. A. Cousens ${ }^{a}$, Leah J. Taylor Kearney ${ }^{a}{ }^{\dagger}$, Matthew T. Clough ${ }^{b}$, Kevin R. J. Lovelock ${ }^{b}$, Robert G. Palgrave ${ }^{c}$, Susan Perkin*a

${ }^{a}$ Department of Chemistry, Physical and Theoretical Chemistry Laboratory, University of Oxford, South Parks Road, Oxford OX1 3QZ, UK.E-mail:susan.perkin@chem.ox.ac.uk

${ }^{b}$ Department of Chemistry, Imperial College London, London SW7 2AZ, UK

'Department of Chemistry, University College London, London WC1H OAJ, UK

${ }^{\dagger}$ Current address: School of Chemistry, National University of Ireland, Galway, University Road, Galway, Ireland

\section{Abstract}

A range of ionic liquids containing dialkylimidazolium cations and halobismuthate anions $\left(\left[\mathrm{BiBr}_{x} \mathrm{Cl}_{y} \mathrm{I}_{z}\right]^{-}\right.$ and $\left.\left[\mathrm{Bi}_{2} \mathrm{Br}_{x} \mathrm{Cl}_{y} \mathrm{I}_{z}\right]^{-}\right)$were synthesised by combining dialkylimidazolium halide ionic liquids with bismuth (III) halide salts. The majority were room temperature liquids, all with very high densities. The neat ionic liquids and their mixtures with 1-butyl-3-methylimidazolium bis(trifluoromethanesulfonyl)imide were characterised using Densitometry, Viscometry, NMR Spectroscopy, Electrospray Ionisation Mass Spectrometry (ESI), Liquid Secondary Ion Mass Spectrometry (LSIMS), Matrix-assisted Laser Desorption/lonization Mass Spectrometry (MALDI), XRay Photoelectron Spectroscopy (XPS) and Thermogravimetric Analysis (TGA), to establish their speciation and suitability for high-temperature applications.

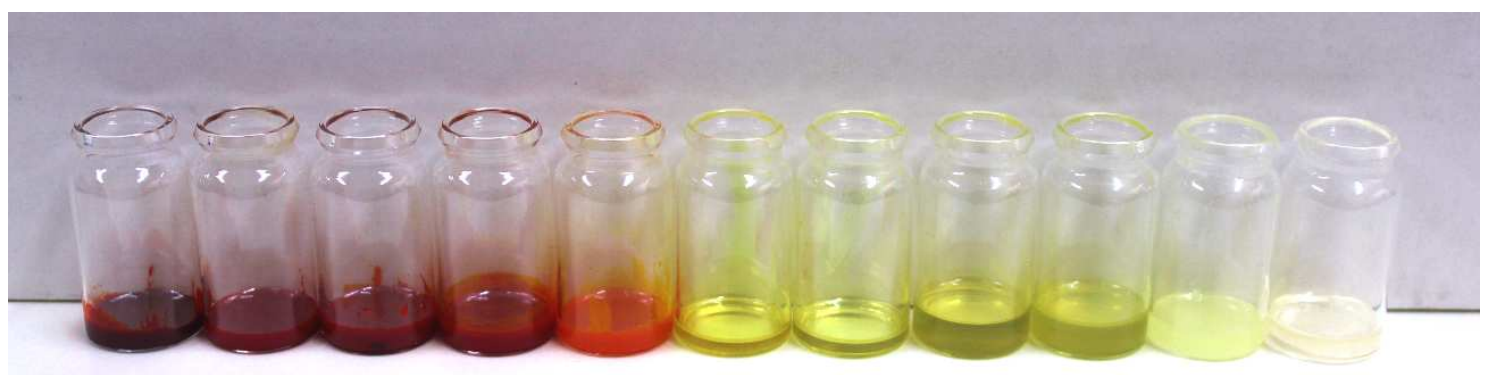

1-butyl-3-methylimidazolium tetrahalobismuthates. Chlorobismuthates are colourless. Upon substitution of chloride for bromide or iodide the liquids become progressively more yellow or red.

\section{Introduction}

Anions consisting of a metal centre coordinated by halide ions are well known in the field of ionic liquids. Indeed, the tetrachloroaluminate anion, $\left[\mathrm{AlCl}_{4}\right]^{-}$, was discovered in the late $1950 \mathrm{~s}$ and was 
the first room temperature 'molten salt' anion. ${ }^{[1]}$ Many similar ions have since been reported such as tetrachloroferrate, $\left[\mathrm{FeCl}_{4}\right]^{-}$; tetrabromoferrate, $\left[\mathrm{FeBr}_{4}\right]^{-}$; and tetrachlorogallate, $\left[\mathrm{GaCl}_{4}\right]^{-{ }^{-2]} \text { When }}$ paired with suitable cations, these form what are commonly termed the 'halometallate' family of ionic liquids. Traditionally seen as solvents for Lewis acidic catalysis and electrochemistry, their applications are broadening, and they now find use in areas as diverse as biomass processing and gas storage ${ }^{[3]}$ This paper reports bismuth based analogues, which have the form $\left[\mathrm{BiX}_{4}\right]^{-}$, where $\mathrm{X}$ is $\mathrm{Cl}^{-}$, $\mathrm{Br}^{-}, \mathrm{I}^{-}$or a mixture of these ions. These bismuthate anions were combined with 1-ethyl-3methylimidazolium $\left(\left[\mathrm{C}_{2} \mathrm{C}_{1} \mathrm{Im}\right]^{+}\right)$and 1-butyl-3-methylimidazolium $\left(\left[\mathrm{C}_{4} \mathrm{C}_{1} \mathrm{Im}\right]^{+}\right)$cations, which are known to readily form room temperature liquids. ${ }^{[4]}$ Mixtures with the ionic liquid 1-butyl-3methylimidazolium bis(trifluoromethylsulfonyl)imide $\left(\left[\mathrm{C}_{4} \mathrm{C}_{1} \mathrm{Im}\right]\left[\mathrm{NTf}_{2}\right]\right)$ were also investigated. The chemistry of bismuth in chloroaluminates has been investigated by Ahmed, Köhler and Ruck, however, to the knowledge of the authors there have been no previous reports of pure halobismuthate ionic liquids. ${ }^{[5]}$

The most common halometallate ionic liquids consist of a group 13 metal centre. Group 13 metal halides are good Lewis acids and as such readily form complexes with electron donating halides, as is the case for $\left[\mathrm{AlCl}_{4}\right]^{-}$. Bismuth also prefers to adopt a 3+ oxidation state due to the inert pair effect and is similarly Lewis acidic due to weak shielding of its nucleus by its 4 electrons. ${ }^{[6]}$ This makes it an excellent candidate as a possible halometallate ion centre, prepared by the addition of a halide ion to a bismuth halide salt. Due to the high molecular weight of bismuth, it was anticipated that the resulting liquids would have higher densities than other metal based ionic liquids.

The halometallates can form various different anionic species in solution depending on, for instance, the amount of $\mathrm{AlCl}_{3}$ added to a chloroaluminate; $\mathrm{Cl}^{-},\left[\mathrm{AlCl}_{4}\right]^{-},\left[\mathrm{Al}_{2} \mathrm{Cl}_{7}\right]^{-}$and $\left[\mathrm{Al}_{3} \mathrm{Cl}_{10}\right]^{-}$species are all known to exist. ${ }^{[7]}$ Given the chemical similarity of bismuth halides to the group 3 halides, the speciation in halobismuthate ionic liquids may be equally interesting and was investigated using Electrospray lonisation Mass Spectrometry (ESI), Liquid Secondary lon Mass Spectrometry (LSIMS), Matrix-assisted Laser Desorption/Ionization Mass Spectrometry (MALDI) and X-Ray Photoelectron Spectroscopy (XPS).

A common issue with ionic liquids is that they can be very viscous, which was found to be the case for the halobismuthate ionic liquids investigated in this study. Ionic liquids incorporating the bis(trifluoromethanesulfonyl)imide, $\left[\mathrm{NTf}_{2}\right]^{-}$, anion are favoured for their low viscosities. ${ }^{[8]}$ Therefore, binary ionic liquid mixtures of one particular halobismuthate ionic liquid, 1-butyl-3methylimidazolium tribromochlorobismuthate, $\left[\mathrm{C}_{4} \mathrm{C}_{1} \mathrm{Im}\right]\left[\mathrm{BiBr}_{3} \mathrm{Cl}\right]$, were prepared by mixing $\left[\mathrm{C}_{4} \mathrm{C}_{1} \mathrm{Im}\right]\left[\mathrm{BiBr}_{3} \mathrm{Cl}\right]$ and $\left[\mathrm{C}_{4} \mathrm{C}_{1} \mathrm{Im}\right]\left[\mathrm{NTf}_{2}\right]$, in an attempt to reduce the viscosity yet retain any attractive chemical and physical properties of the new liquids. An alternative solution is to work with the ionic liquids at elevated temperatures. Therefore, the thermal stability of the liquids was studied by Thermogravimetric Analysis and their viscosities as a function of temperature are also reported.

\section{$\underline{2 \text { Results and discussion }}$}

\subsection{Synthesis and stability}


A range of ionic liquids incorporating the $\left[\mathrm{C}_{2} \mathrm{C}_{1} I \mathrm{~m}\right]^{+}$and $\left[\mathrm{C}_{4} \mathrm{C}_{1} \mathrm{Im}\right]^{+}$cations and $\left[\mathrm{BiBr}_{x} \mathrm{Cl}_{y} \mathrm{I}_{z}\right]^{-}$or $\left[\mathrm{Bi}_{2} \mathrm{Br}_{x} \mathrm{Cl}_{y} \mathrm{I}_{z}\right]^{-}$anions, where $x, y$ and $z$ indicate varying stoichiometries of each halide, were successfully synthesised (Figure 1 and Table 1 ). At $100{ }^{\circ} \mathrm{C}$ all were translucent, homogenous liquids. Chloride-containing liquids were colourless, bromide-containing liquids yellow and iodide-containing liquids red/purple in appearance. Upon cooling to room temperature certain liquids, as reported in Table 1, became opaque and solidified. Of the wide range of bismuthate ionic liquids prepared, $\left[\mathrm{C}_{4} \mathrm{C}_{1} \mathrm{Im}\right]\left[\mathrm{BiBr}_{3} \mathrm{Cl}\right],\left[\mathrm{C}_{4} \mathrm{C}_{1} \mathrm{Im}\right]\left[\mathrm{BiBr}_{3} \mathrm{l}\right],\left[\mathrm{C}_{4} \mathrm{C}_{1} \mathrm{Im}\right]\left[\mathrm{Bi}_{2} \mathrm{Br}_{7}\right]$ and $\left[\mathrm{C}_{4} \mathrm{C}_{1} \mathrm{Im}\right]\left[\mathrm{Bi}_{2} \mathrm{Br}_{6}\right]$, as well as mixtures of $\left[\mathrm{C}_{4} \mathrm{C}_{1} \mathrm{Im}\right]\left[\mathrm{BiBr}_{3} \mathrm{Cl}\right]$ with $\left[\mathrm{C}_{4} \mathrm{C}_{1} I \mathrm{~m}\right]\left[\mathrm{NTf}_{2}\right]$, were chosen for further characterisation as these ionic liquids cover a broad variety of anions.

\section{$\left[\mathrm{C}_{4} \mathrm{C}_{1} \mathrm{Im}\right]\left[\mathrm{BiBr}_{3} \mathrm{Cl}\right]$}

${ }^{1} \mathrm{H}$ NMR (400 MHz, Acetone-d6): $\delta 9.13(1 \mathrm{H}, \mathrm{s}), 7.75(1 \mathrm{H}, \mathrm{t}, \mathrm{J}=2 \mathrm{~Hz}), 7.71(1 \mathrm{H}, \mathrm{t}, \mathrm{J}=2 \mathrm{~Hz}), 4.43(2 \mathrm{H}, \mathrm{t}$, $\mathrm{J}=7 \mathrm{~Hz}), 4.11(3 \mathrm{H}, \mathrm{s}), 2.01-1.90(2 \mathrm{H}, \mathrm{m}), 1.46-1.34(2 \mathrm{H}, \mathrm{m}), 0.95(3 \mathrm{H}, \mathrm{t}, \mathrm{J}=7 \mathrm{~Hz}) .{ }^{13} \mathrm{C} \mathrm{NMR}(100$ $\mathrm{MHz}$, Acetone-d6): $\delta$ 137.2, 124.9, 123.4, 50.5, 37.4, 32.9, 20.1, 13.8. m/z (ESI $\left.{ }^{+}\right): 139$ (100\%) $\left[\mathrm{C}_{4} \mathrm{C}_{1} \mathrm{Im}\right]^{+}, 83(7 \%)\left[\mathrm{C}_{1} \mathrm{HIm}\right]^{+} . \mathrm{m} / \mathrm{z}\left(\mathrm{ESI}^{-}\right): 515(100 \%)\left[\mathrm{BiBr}_{4}\right]^{-}, 298(69 \%)\left[\mathrm{C}_{4} \mathrm{C}_{1} \mathrm{ImBr}_{2}\right]^{-}, 471(36 \%)$

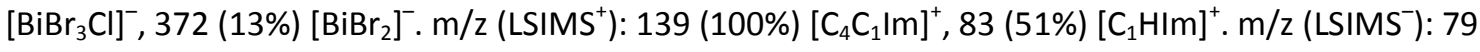
(100\%) ${ }^{79} \mathrm{Br}^{-}, 81(97 \%){ }^{81} \mathrm{Br}^{-}, 489$ (2\%) $\left[\mathrm{BiBr}_{3} \mathrm{Cl}\right]^{-} . \mathrm{m} / \mathrm{z}$ (MALDI $): 528$ (100\%) [ $\left.\mathrm{BiBr}_{4}\right]^{-}, 484$ (71\%) $\left[\mathrm{BiBr}_{3} \mathrm{Cl}\right]^{-}, 294$ (39\%) $\left[\mathrm{C}_{4} \mathrm{C}_{1} 1 \mathrm{mBr}_{2}\right]^{-}, 438(26 \%)\left[\mathrm{BiBr}_{2} \mathrm{Cl}_{2}\right]^{-}, 637(2 \%)\left[\mathrm{C}_{4} \mathrm{C}_{1} 1 \mathrm{mBi}{ }_{2} \mathrm{Br}^{-}\right.$.

\section{$\left[\mathrm{C}_{4} \mathrm{C}_{1} \mathrm{Im}\right]\left[\mathrm{BiBr}_{3} \mathrm{I}\right]$}

${ }^{1} \mathrm{H}$ NMR (400 MHz, Acetone-d6): $\delta 9.11(1 \mathrm{H}, \mathrm{s}), 7.76(1 \mathrm{H}, \mathrm{t}, \mathrm{J}=2 \mathrm{~Hz}), 7.72(1 \mathrm{H}, \mathrm{t}, \mathrm{J}=2 \mathrm{~Hz}), 4.43(2 \mathrm{H}, \mathrm{t}$, $\mathrm{J}=8 \mathrm{~Hz}), 4.12(3 \mathrm{H}, \mathrm{s}), 2.02-1.91(2 \mathrm{H}, \mathrm{m}), 1.47-1.35(2 \mathrm{H}, \mathrm{m}), 0.95(3 \mathrm{H}, \mathrm{t}, \mathrm{J}=7 \mathrm{~Hz}) .{ }^{13} \mathrm{C} \mathrm{NMR}(100$ $\mathrm{MHz}$, Acetone-d6): $\delta 137.1,124.9,123.5,50.6,37.4,32.9,20.1,13.8 . \mathrm{m} / \mathrm{z}\left(\mathrm{ESI}^{+}\right): 139$ (100\%) $\left[\mathrm{C}_{4} \mathrm{C}_{1} \mathrm{Im}\right]^{+}, 83(2 \%)\left[\mathrm{C}_{1} \mathrm{HIm}\right]^{+} . \mathrm{m} / \mathrm{z}\left(\mathrm{ESI}^{-}\right): 517(100 \%)\left[\mathrm{BiBr}_{4}\right]^{-}, 563(70 \%)\left[\mathrm{BiBr}_{3} \mathrm{I}\right]^{-}, 298(47 \%)$ $\left[\mathrm{C}_{4} \mathrm{C}_{1} \mathrm{ImBr}_{2}\right]^{-}, 609$ (19\%) [BiBr $\left.\mathrm{I}_{2}\right]^{-} . \mathrm{m} / \mathrm{z}\left(\mathrm{LSIMS}^{+}\right): 83(74 \%)\left[\mathrm{C}_{1} \mathrm{HIm}\right]^{+}, 139(100 \%)\left[\mathrm{C}_{4} \mathrm{C}_{1} \mathrm{Im}\right]^{+} . \mathrm{m} / \mathrm{z}\left(\mathrm{LSIMS}^{-}\right.$ ): $79(100 \%){ }^{79} \mathrm{Br}^{-}, 81(97 \%){ }^{81} \mathrm{Br}^{-}, 127$ (31\%) $\mathrm{I}^{-}, 531$ (12\%) $\left[\mathrm{BiBr}_{4}\right]^{-}, 580(10 \%)\left[\mathrm{BiBr}_{3} \mathrm{l}\right]^{-}, 452$ (7\%) $\left[\mathrm{BiBr}_{3}\right]^{-}, 371$ (6\%) $\left[\mathrm{BiBr}_{2}\right]^{-}, 498$ (6\%) $\left[\mathrm{BiBr}_{2} \mathrm{I}_{2}\right]^{-}, 160(5 \%)\left[\mathrm{Br}_{2}\right]^{-}, 207$ (2\%) [Brl] $]^{-} \mathrm{m} / \mathrm{z}\left(\mathrm{MALDI}^{-}\right): 528$ $(100 \%)\left[\mathrm{BiBr}_{4}\right]^{-}, 574(69 \%)\left[\mathrm{BiBr}_{3}\right]^{-}, 637(99 \%)\left[\mathrm{C}_{4} \mathrm{C}_{1} \mathrm{ImBi}_{2} \mathrm{Br}\right]^{-}$.

\section{$\left[\mathrm{C}_{4} \mathrm{C}_{1} \operatorname{lm}\right]\left[\mathrm{Bi}_{2} \mathrm{Br}_{7}\right]$}

m/z (LSIMS $\left.{ }^{+}\right): 83$ (72\%) [C $\left.\mathrm{Clm}_{1}\right]^{+}, 139$ (73\%) $\left[\mathrm{C}_{4} \mathrm{C}_{1} \mathrm{Im}\right]^{+} . \mathrm{m} / \mathrm{z}\left(\mathrm{LSIMS}^{-}\right): 527(100 \%)\left[\mathrm{BiBr}_{4}\right]^{-}, 446(32 \%)$ $\left[\mathrm{BiBr}_{3}\right]^{-}, 367$ (23\%) $\left[\mathrm{BiBr}_{2}\right]^{-}, 293(8 \%)\left[\mathrm{C}_{4} \mathrm{C}_{1} \mathrm{ImBiBr}_{3}\right]^{2-}, 657(5 \%)\left[\mathrm{Bi}_{2} \mathrm{Br}_{3}\right]^{-}, 1197(5 \%)\left[\mathrm{Bi}_{3} \mathrm{Br}_{7}\right]^{-}, 740(3 \%)$ $\left[\mathrm{Bi}_{2} \mathrm{Br}_{4}\right]^{-}, 815(3 \%)\left[\mathrm{Bi}_{2} \mathrm{Br}_{5}\right]^{-}, 976(2 \%)\left[\mathrm{Bi}_{2} \mathrm{Br}_{7}\right]^{-}$.

\section{$\left[\mathrm{C}_{4} \mathrm{C}_{1} \mathrm{Im}\right]\left[\mathrm{Bi}_{2} \mathrm{BrI}_{6}\right]$}

m/z (LSIMS $\left.{ }^{+}\right): 83$ (53\%) [C $\left.\mathrm{C}_{1} \mathrm{Him}\right]^{+}, 139(67 \%)\left[\mathrm{C}_{4} \mathrm{C}_{1} \mathrm{Im}\right]^{+} . \mathrm{m} / \mathrm{z}\left(\mathrm{LSIMS}^{-}\right): 293(100 \%)\left[\mathrm{C}_{4} \mathrm{C}_{1} \mathrm{ImBiBr}_{3}\right]^{2-}, 527$ (63\%) $\left[\mathrm{BiBr}_{4}\right]^{-},(62 \%) 714\left[\mathrm{Bil}_{4}\right]^{-}, 339(48 \%)[\mathrm{Bil}]^{-}, 588(48 \%)\left[\mathrm{Bil}_{3}\right]^{-}, 461$ (37\%) $\left[\mathrm{Bil}_{2}\right]^{-}, 669(28 \%)$ $\left[\mathrm{BiBrl}_{3}\right]^{-}, 413$ (15\%) [BiBrl], 446 (27\%) $\left[\mathrm{BiBr}_{3}\right]^{-}, 620$ (13\%) $\left[\mathrm{Bi}_{2} \mathrm{Brl}^{-}, 494(8 \%)\left[\mathrm{BiBr}_{2}\right]^{-}, 1051\right.$ (4\%) $\left[\mathrm{Bi}_{2} \mathrm{I}_{5}\right]^{-}, 797(4 \%)\left[\mathrm{Bi}_{2} \mathrm{I}_{3}\right]^{-}, 749(3 \%)\left[\mathrm{Bi}_{2} \mathrm{Brl}_{2}\right]^{-}, 830(3 \%)\left[\mathrm{Bi}_{2} \mathrm{Br}_{2} \mathrm{I}_{2}\right]^{-}, 1487(3 \%)\left[\mathrm{Bi}_{3} \mathrm{Br}_{6} \mathrm{I}_{3}\right]^{-}$.

${ }^{1} \mathrm{H}$ and ${ }^{13} \mathrm{C}$ NMR spectra and ESI, LSIMS and MALDI mass spectra confirm the presence of the $\left[\mathrm{C}_{4} \mathrm{C}_{1} \mathrm{Im}\right]^{+}$cation. Speciation of the anions is discussed in section 2.7 . It should be noted that many of 
the peaks in the mass spectra could not be assigned (see supplementary information, Figures S1 to S14), and those that were, were done so with caution. ${ }^{35} \mathrm{Cl}$ and ${ }^{79} \mathrm{Br} \mathrm{NMR}$ experiments were attempted to see if it would be possible to distinguish different environments for the halide ligands in axial and equatorial positions, however, no peaks were distinguishable from the baseline noise.

When mixed with water the liquids formed a white solid, presumably containing mixed bismuth (III) oxy halide compounds, however no degradation of the liquids was observed when left open to the air even after a period of several months. This is in stark contrast to the well-understood haloaluminate ionic liquids, which hydrolyse immediately upon contact with moisture in the air. It should also be noted that bismuth itself, despite being a 'heavy metal', is non-toxic. ${ }^{[9]}$

\subsection{Density}

The densities of the liquids are remarkably high (Table 1), presumably due in part to the high molar mass of bismuth (bismuth is the heaviest stable element in the periodic table). The densest liquid in the series, $\left[\mathrm{C}_{4} \mathrm{C}_{1} \mathrm{Im}\right]\left[\mathrm{Bi}_{2} \mathrm{Br}_{6}\right]$, has a density of $3.46 \pm 0.05 \mathrm{~g} \mathrm{~cm}^{-3}$ (at $100{ }^{\circ} \mathrm{C}$ ), although this was not a liquid at room temperature. This density is more than double that of common ionic liquids (e.g. $\left.\left[\mathrm{C}_{4} \mathrm{C}_{1} \mathrm{Im}\right]\left[\mathrm{NTf}_{2}\right]=1.43 \mathrm{~g} \mathrm{~cm}^{-3}\right) \cdot{ }^{[8]}$ According to Welton and Wasserscheid, the highest known ionic liquid density is $2.4 \mathrm{~g} \mathrm{~cm}^{-3}$ for $\left[\left(\mathrm{CH}_{3}\right)_{3} \mathrm{~S}\right]\left[\mathrm{Al}_{2} \mathrm{Br}_{7}\right] \cdot{ }^{[8]}$ The densest room temperature liquid in our investigation was $\left[\mathrm{C}_{4} \mathrm{C}_{1} \mathrm{Im}\right]\left[\mathrm{BiBr}_{3} \mathrm{Cl}\right]\left[\mathrm{BiBr}_{3}\right]_{0.5}$, with a density of $2.65 \pm 0.05 \mathrm{~g} \mathrm{~cm}^{-3}$.

The density of the liquids correlates with the molecular weight of the halide ligands: $\left[\mathrm{C}_{4} \mathrm{C}_{1} \mathrm{Im}\right]\left[\mathrm{BiBr}_{3} \mathrm{Cl}\right]$ had a density of $2.41 \pm 0.05 \mathrm{~g} \mathrm{~cm}^{-3},\left[\mathrm{C}_{4} \mathrm{C}_{1} \mathrm{Im}\right]\left[\mathrm{BiBr}_{4}\right]$ had a density of $2.49 \pm 0.05 \mathrm{~g}$ $\mathrm{cm}^{-3}$ and $\left.\left[\mathrm{C}_{4} \mathrm{C}_{1} \mathrm{Im}\right]\left[\mathrm{BiBr}_{3}\right]\right]$ had a density of $2.63 \pm 0.05 \mathrm{~g} \mathrm{~cm}^{-3}$. This trend is also seen in the literature for haloaluminates $\left(\left[\mathrm{C}_{2} \mathrm{C}_{1} \mathrm{Im}\right]\left[\mathrm{AlCl}_{4}\right]=1.27 \mathrm{~g} \mathrm{~cm}^{-3},\left[\mathrm{C}_{2} \mathrm{C}_{1} \mathrm{Im}\right]\left[\mathrm{AlBr}_{4}\right]=1.92 \mathrm{~g} \mathrm{~cm}^{-3}\right.$ at $\left.50{ }^{\circ} \mathrm{C}\right)$ and haloferrates $\left(\left[\mathrm{C}_{4} \mathrm{C}_{1} \mathrm{Im}\right]\left[\mathrm{FeCl}_{4}\right]=1.38 \mathrm{~g} \mathrm{~cm}^{-3},\left[\mathrm{C}_{4} \mathrm{C}_{1} \mathrm{Im}\right]\left[\mathrm{FeBr}_{4}\right]=1.98 \mathrm{~g} \mathrm{~cm}^{-3}\right.$ at $\left.25^{\circ} \mathrm{C}\right) .{ }^{[10]}$

\subsection{Thermal stability}

Halobismuthate ionic liquids may find use in high-temperature applications, and as such it is important to understand their thermal stability. The thermal stabilities of $\left[\mathrm{C}_{4} \mathrm{C}_{1} \mathrm{Im}\right]\left[\mathrm{BiCl}_{4}\right]$, $\left[\mathrm{C}_{4} \mathrm{C}_{1} \mathrm{Im}\right]\left[\mathrm{BiBr}_{3} \mathrm{Cl}\right],\left[\mathrm{C}_{4} \mathrm{C}_{1} \mathrm{Im}\right]\left[\mathrm{BiBr}_{4}\right],\left[\mathrm{C}_{4} \mathrm{C}_{1} \mathrm{Im}\right]\left[\mathrm{BiBr}_{3} \mathrm{I}\right]$ and $\left[\mathrm{C}_{4} \mathrm{C}_{1} \mathrm{Im}\right]\left[\mathrm{BiBr}_{3} \mathrm{Cl}_{0.5}\left[\mathrm{NTf}_{2}\right]_{0.5}\right.$ were measured using temperature-ramped Thermogravimetric Analysis (TGA), and are compared in Figure 2 and Table 2. The $T_{\text {onset }}$ thermal decomposition temperatures were determined from extrapolation of the steepest point of the thermograph. $T_{\text {onset }}$ temperatures of the measured halobismuthate liquids, with the exception of $\left[\mathrm{C}_{4} \mathrm{C}_{1} \mathrm{Im}\right]\left[\mathrm{BiCl}_{4}\right]$, are similar and high (between $370^{\circ} \mathrm{C}$ to $380{ }^{\circ} \mathrm{C}$ ). By contrast, $\left[\mathrm{C}_{4} \mathrm{C}_{1} \mathrm{Im}\right]\left[\mathrm{BiCl}_{4}\right]$ decomposed in a multi-step fashion, with a $T_{\text {onset }}$ value of $260^{\circ} \mathrm{C}$ corresponding to the first step of weight loss. This $T_{\text {onset }}$ value compares reasonably favourably with that of the ionic liquid $\left[\mathrm{C}_{4} \mathrm{C}_{1} \mathrm{Im}\right] \mathrm{Cl}$ (measured as $275{ }^{\circ} \mathrm{C}$ under the same experimental conditions), suggesting that the chloride ligands in the $\left[\mathrm{BiCl}_{4}\right]^{-}$anion may be more labile and free to attack the dialkylimidazolium cation than in the other halobismuthate analogues.

The addition of $\left[\mathrm{C}_{4} \mathrm{C}_{1} \mathrm{Im}\right]\left[\mathrm{NTf}_{2}\right]$ to reduce the viscosity (section 2.5 ) appears to have no detrimental effect on the thermal stability. This implies that these mixtures are suitable for use at elevated temperatures. It is well established that $T_{\text {onset }}$ dramatically overestimates the thermal stability of ionic liquids, but is still a useful parameter for comparing the relative stabilities of ionic liquids. ${ }^{[11]}$ 
However, the very high $T_{\text {onset }}$ values $\left(>370^{\circ} \mathrm{C}\right.$ ) for the halobismuthate ionic liquids suggest that they would be stable at temperatures in excess of $200^{\circ} \mathrm{C}$ for extended periods of time.

It is unclear whether TGA mass loss is due to decomposition or vaporisation of the liquids, or a combination of these processes. The fact that $T_{\text {onset }}$ values are well below the boiling points of the composite bismuth halides $\left(\mathrm{BiCl}_{3}, \mathrm{BiBr}_{3}\right.$ or $\mathrm{Bil}_{3}$ which boil at $447{ }^{\circ} \mathrm{C}, 453^{\circ} \mathrm{C}$ and $542{ }^{\circ} \mathrm{C}$ respectively) suggests that mass loss is primarily due to decomposition. ${ }^{[12]}$

\subsection{Glass transition temperature $\left(T_{\mathrm{g}}\right)$}

The liquids $\left[\mathrm{C}_{4} \mathrm{C}_{1} \mathrm{Im}\right]\left[\mathrm{BiBr}_{3} \mathrm{Cl}\right],\left[\mathrm{C}_{4} \mathrm{C}_{1} \mathrm{Im}\right]\left[\mathrm{BiBr}_{4}\right],\left[\mathrm{C}_{4} \mathrm{C}_{1} \mathrm{Im}\right]\left[\mathrm{BiBr}_{3} \mathrm{Cl}\right]\left[\mathrm{BiBr}_{3}\right]_{0.5}$ and $\left.\left[\mathrm{C}_{4} \mathrm{C}_{1} \mathrm{Im}\right]\left[\mathrm{BiBr}_{3}\right]\right]$ are room temperature liquids (Table 1). Upon decreasing the length of the alkyl chain on the imidazolium ring from $\left[\mathrm{C}_{4} \mathrm{C}_{1} \mathrm{Im}\right]^{+}$to $\left[\mathrm{C}_{2} \mathrm{C}_{1} \mathrm{Im}\right]^{+}$with the $\left[\mathrm{BiBr}_{3} \mathrm{Cl}\right]^{-}$anion, $T_{\mathrm{g}}$ increases, possibly due to closer packing of the ions and hence stronger Coulomb attractions. $\left[\mathrm{C}_{4} \mathrm{C}_{1} \mathrm{Im}\right]\left[\mathrm{Bi}_{2} \mathrm{Br}_{6} \mathrm{Cl}\right]$ and $\left[\mathrm{C}_{4} \mathrm{C}_{1} \mathrm{Im}\right]\left[\mathrm{BiBrl}_{3}\right]$ are liquids above $50{ }^{\circ} \mathrm{C}$ while $\left[\mathrm{C}_{4} \mathrm{C}_{1} \mathrm{Im}\right]\left[\mathrm{Bi}_{2} \mathrm{Br}_{6}\right]$ is a liquid above $100^{\circ} \mathrm{C}$. This trend of increasing $T_{\mathrm{g}}$ with increasing $\mathrm{I}^{-}$content can be explained by the increasing van der Waals attractions between the more polarisable $\Gamma^{-}$ligands. ${ }^{[13]}$ The $T_{\mathrm{g}}$ of all the ionic liquids was well below the melting points of the component compounds, suggesting that new chemical species had formed.

\subsection{Viscosity}

The room temperature viscosities of $\left[\mathrm{C}_{4} \mathrm{C}_{1} \mid \mathrm{m}\right]\left[\mathrm{BiBr}_{3} \mathrm{Cl}\right]$ and $\left[\mathrm{C}_{4} \mathrm{C}_{1} \mid \mathrm{m}\right]\left[\mathrm{BiBr}_{3} \mid\right]$ were measured (Table 1 ). The viscosity of iodide-containing $\left[\mathrm{C}_{4} \mathrm{C}_{1} \mid \mathrm{m}\right]\left[\mathrm{BiBr}_{3} \mathrm{l}\right]$ is greater than its chloride analogue, $\left[\mathrm{C}_{4} \mathrm{C}_{1} \mathrm{Im}\right]\left[\mathrm{BiBr}_{3} \mathrm{Cl}\right]$ (1517 $\mathrm{Pa}$ s and $648 \mathrm{~Pa} \mathrm{~s}$ at $25^{\circ} \mathrm{C}$, respectively), although both liquids are still very viscous. As described above, the liquid $\left[\mathrm{C}_{4} \mathrm{C}_{1} \mathrm{Im}\right]\left[\mathrm{BiBr}_{3} \mathrm{Cl}\right]$ offers the following interesting and beneficial properties: (i) very high density; (ii) high thermal stability; (iii) a melting point below room temperature; (iv) ease of preparation. However, the very high viscosity of this ionic liquid limits its use at room temperature. Therefore, the effect of adding the prototypical ionic liquid $\left[\mathrm{C}_{4} \mathrm{C}_{1} \mathrm{Im}\right]\left[\mathrm{NTf} \mathrm{f}_{2}\right]$, which has a much lower viscosity of $0.052 \mathrm{~Pa} \mathrm{~s}$, was investigated. ${ }^{[8]}$ The density of $\left[\mathrm{C}_{4} \mathrm{C}_{1} \mathrm{Im}\right]\left[\mathrm{BiBr}_{3} \mathrm{Cl}\right] /\left[\mathrm{C}_{4} \mathrm{C}_{1} \mathrm{Im}\right]\left[\mathrm{NTf}_{2}\right]$ mixtures is shown in Figure 3a. A $50: 50$ mol\% ratio lowers the viscosity of $\left[\mathrm{C}_{4} \mathrm{C}_{1} \mathrm{~lm}\right]\left[\mathrm{BiBr}_{3} \mathrm{Cl}\right]$ from $648 \mathrm{~Pa} \mathrm{~s}$ to $1.37 \mathrm{~Pa} \mathrm{~s}$, making it convenient to handle at room temperature. Thus, the viscosity of these mixtures was far lower than the parent halobismuthate ionic liquid, yet the density was still high and the thermal stability was not compromised (Figure 2). Below 50 mol\% of the halobismuthate ionic liquid, the mixtures were no longer stable and the $\left[\mathrm{BiBr}_{3} \mathrm{Cl}\right]^{-}$ion appeared to separate into $\mathrm{Cl}^{-}$and $\mathrm{BiBr}_{3}$, which precipitated as a yellow solid.

Alternatively, the viscosity can be reduced by increasing the temperature. The effect of temperature on viscosity is shown in Figure $3 \mathrm{~b}$. As expected, there is a dramatic decrease in viscosity as the temperature is increased. At $85{ }^{\circ} \mathrm{C}$ the viscosity of pure $\left[\mathrm{C}_{4} \mathrm{C}_{1} \mathrm{Im}\right]\left[\mathrm{BiBr}_{3} \mathrm{Cl}\right]$ drops to $2.82 \mathrm{~Pa}$ s. Given the good thermal stability of the liquids, raising the temperature is clearly an effective method for reducing the viscosity of halobismuthate liquids.

As water content is known to have a substantial effect on viscosity, prior to viscosity measurements the liquids were dried overnight in a dessicator at $<0.1 \mathrm{mbar}$ and then stored under dry nitrogen. The water content of the liquids was measured immediately after exposure to the ambient atmosphere and then again after 10 minutes and 30 minutes. ${ }^{[8]}$ Water uptake was extremely slow; the water content varied from $224 \mathrm{ppm}$ to $470 \mathrm{ppm}$ for $\left[\mathrm{C}_{4} \mathrm{C}_{1} \mathrm{Im}\right]\left[\mathrm{BiBr}_{3} \mathrm{Cl}\right]_{0.5}\left[\mathrm{NTf}_{2}\right]_{0.5}$. 


\subsection{X-ray Photoelectron Spectroscopy (XPS)}

Two pieces of information available from XPS are of use in this study: composition and electron binding energies. Binding energies are used to determine the number of electronic environments present in the samples, and are of primary interest here. In addition, the composition by XPS is compared to the expected bulk stoichiometric composition to check that the samples were of high purity.

For the composition, relative sensitivity factors (RSFs) from Kolbeck et al. are used for all elements apart from bismuth (Table 3). These RSFs were determined for a range of ionic liquids. ${ }^{[14]}$ Note that the Kolbeck RSFs for $\mathrm{Cl}$ and $\mathrm{Br}$ were determined for $\mathrm{Cl} 2 \mathrm{p}$ and $\mathrm{Br} 3 \mathrm{~d}$ peak areas, whereas here the $\mathrm{Cl}$ $2 p_{3 / 2}$ and $B r 3 d_{5 / 2}$ peak areas are used; therefore, the Kolbeck RSFs are multiplied by $2 / 3$ to account for the different peaks used. The RSF for Bi used is 4.25 , taken from Wagner et al. ${ }^{[15]}$ The error in experimental composition is estimated as $\pm 10 \%$. The information depth (ID) of XPS experiments can be defined as the depth, within the sample, from which $95 \%$ of the measured signal will originate. ID is assumed to vary mainly with $\cos \theta$, where $\theta$ is the electron emission angle relative to the surface normal. If it is assumed that the inelastic mean free path $(\lambda)$ of photoelectrons in organic compounds is of the order of $\sim 3 \mathrm{~nm}$, at the kinetic energies employed here the ID in this geometry can be estimated, when $\theta=0^{\circ}$, ID $=7-9 \mathrm{~nm} \cdot{ }^{[16]}$ Consequently, these data may be considered as representative of the bulk composition and do not reflect any local enhancements of concentration at the near surface region.

When comparing the nominal and XPS experimental compositions, it is best to start with a reference ionic liquid, $\left[\mathrm{C}_{8} \mathrm{C}_{1} \mathrm{Im}\right] \mathrm{Br}$. The nominal and XPS experimental compositions are the same, within the error of the experiment, for the carbon and nitrogen regions. The nominal and XPS experimental compositions are slightly different for $\mathrm{Br}$ for $\left[\mathrm{C}_{8} \mathrm{C}_{1} \mathrm{Im}\right] \mathrm{Br}$, indicating that the $\mathrm{Br} 3 \mathrm{~d}_{5 / 2} \mathrm{RSF}$ is slightly too large. If $\mathrm{RSF}\left(\mathrm{Br} 3 \mathrm{~d}_{5 / 2}\right)=0.330$ is used, the $\mathrm{Br}$ nominal and XPS experimental compositions match very well. Overall, the good match between nominal and XPS experimental compositions confirms the reliability of the RSFs used, the purity of $\left[\mathrm{C}_{8} \mathrm{C}_{1} \mathrm{Im}\right] \mathrm{Br}$, and the XPS system used here. For the four halobismuthate ionic liquids, the nominal and XPS experimental compositions match well. As for $\left[\mathrm{C}_{8} \mathrm{C}_{1} \mathrm{Im}\right] \mathrm{Br}$, the experimental XPS number of atoms for $\mathrm{Br}$ is in all cases slightly lower than the nominal number of atoms. Again, if $\operatorname{RSF}\left(\mathrm{Br}_{3} \mathrm{~d}_{5 / 2}\right)=0.330$ is used, the $\mathrm{Br}$ nominal and XPS experimental compositions match very well for the halobismuthate ionic liquids. The experimental XPS numbers of atoms for bismuth is in all cases slightly lower than the nominal number of atoms. This observation could be due to there being less bismuth in the ionic liquids than expected, or because the $\operatorname{RSF}\left(\mathrm{Bi}_{4 \mathrm{f}_{7 / 2}}\right)$ is slightly too low. As the result is consistent across all four halobismuthate ionic liquids, it can be concluded that the $\operatorname{RSF}\left(\mathrm{Bi}_{4 \mathrm{f}_{7 / 2}}\right)$ is slightly too low. It should be noted that there is a small amount of bismuth metal contamination (ratio of peak areas for $\mathrm{Bi}(\mathrm{III}): \mathrm{Bi}($ metal) is 6.1) for $\left[\mathrm{C}_{4} \mathrm{C}_{1} \mathrm{Im}\right]\left[\mathrm{BiBr}_{4}\right]_{0.67} \mathrm{Br}_{0.33}$. This metal contamination is very likely due to sample degradation by the X-ray source, not due to the presence of bismuth metal in the sample at the start of the experiment. Such sample degradation is commonly observed for XPS. ${ }^{[17]}$ The bismuth region was recorded at the end of the XPS experiment; therefore, the results for $\left[\mathrm{C}_{4} \mathrm{C}_{1} \mathrm{Im}\right]\left[\mathrm{BiBr}_{4}\right]_{0.67} \mathrm{Br}_{0.33}$ can be used to probe the electronic environment of $\left[\mathrm{C}_{4} \mathrm{C}_{1} \mathrm{Im}\right]\left[\mathrm{BiBr}_{4}\right]_{0.67} \mathrm{Br}_{0.33}$ with confidence. Due to the relatively small amount of bismuth metal contamination, it is not expected that this metal had any effect on the XPS results for the other regions for $\left[\mathrm{C}_{4} \mathrm{C}_{1} I \mathrm{Im}\right]\left[\mathrm{BiBr}_{4}\right]_{0.67} \mathrm{Br}_{0.33}$. All elements expected to be present in the samples are observed, and no extra elements are observed, aside from a small 
amount of oxygen contamination for $\left[\mathrm{C}_{4} \mathrm{C}_{1} \mathrm{Im}\right]\left[\mathrm{BiBr}_{4}\right]_{0.67} \mathrm{Br}_{0.33}$ ( 0.5 atoms in the sample). This oxygen contamination is likely to be due to X-ray degradation of the sample, or the presence of water impurity in the solid. Therefore, it can be concluded that the compositions of the ionic liquids probed by XPS match well with the nominal compositions; therefore, information about the electronic environments of the ionic liquids can be obtained with good confidence that ionic liquids were of high purity.

To be able to directly compare binding energies for different ionic liquids, it is necessary to charge correct all XP spectra. For a wide range of imidazolium-based ionic liquids, the $C_{\text {alkyl }} 1$ s peak has successfully been used for charge correction. ${ }^{[18]}$ For all five ionic liquids studied here, two distinct peaks with a shoulder at higher energies are observed for C 1s region (Figures S15-S19), as expected based upon previous results for XPS of imidazolium-based ionic liquids. ${ }^{[18]}$ In addition, there is a very broad shake-up feature at $\sim 293 \mathrm{eV}$, also as expected for $\left[\mathrm{C}_{n} \mathrm{C}_{1} \mathrm{Im}\right]^{+}$-based ionic liquids (where $n \geq$ 2). ${ }^{[18 c]}$ Therefore, there are three different electronic environments for carbon atoms in all five of the ionic liquids studied here. The lower energy peak is assigned as $C_{\text {alkyl }} 1 \mathrm{~s}$; the higher energy peak and shoulder are assigned as $C_{\text {hetero }} 1 \mathrm{~s}$. All C $1 \mathrm{~s}$ XP spectra are fitted with three peaks, and give a very good fit (Figures S15-S19). The binding energy of the $C_{\text {alkyl }} 1$ s peak is set to $285.0 \mathrm{eV}$, and all of the other peaks are corrected by the same amount. This charge correction procedure allows comparison of the binding energies for different ionic liquids. Using $C_{\text {alkyl }} 1 \mathrm{~s}$ for charge correction for $\left[\mathrm{C}_{4} \mathrm{C}_{1} \mathrm{Im}\right][\mathrm{A}]$ gives an error of $\pm 0.2 \mathrm{eV}$, larger than the $\pm 0.1 \mathrm{eV}$ error associated with studying $\left[C_{8} C_{1} I m\right][A]$. Binding energies from the XP spectra of $\left[C_{4} C_{1} I m\right]\left[B_{B B r} C_{3}\right], \quad\left[C_{4} C_{1} I m\right]\left[B_{B B r}\right]$, $\left[\mathrm{C}_{4} \mathrm{C}_{1} \mathrm{Im}\right]\left[\mathrm{BiBr}_{3} I\right],\left[\mathrm{C}_{4} \mathrm{C}_{1} \mathrm{Im}\right]\left[\mathrm{BiBr}_{4}\right]_{0.67} \mathrm{Br}_{0.33}$ and $\left[\mathrm{C}_{8} \mathrm{C}_{1} \mathrm{Im}\right] \mathrm{Br}$ are shown in Table 4.

The three ionic liquids that are viscous liquids at room temperature $\left(\left[\mathrm{C}_{4} \mathrm{C}_{1} \mathrm{Im}\right]\left[\mathrm{BiBr}_{3} \mathrm{Cl}\right]\right.$, $\left.\left[\mathrm{C}_{4} \mathrm{C}_{1} \mathrm{Im}\right]\left[\mathrm{BiBr}_{4}\right],\left[\mathrm{C}_{4} \mathrm{C}_{1} \mathrm{Im}\right]\left[\mathrm{BiBr}_{3} \mathrm{I}\right]\right)$ give two peaks in the $\mathrm{Bi} 4 \mathrm{f}$ region, $4 \mathrm{f}_{5 / 2}$ and $4 \mathrm{f}_{7 / 2}$, which are due to spin orbit coupling (Figure 4a). Therefore, for these three ionic liquids there is one bismuth electronic environment only. The binding energies for the $\mathrm{Bi}_{4 / 2}$ peak for all three ionic liquids are the same (within the error of the experiment), $159.8 \pm 0.1 \mathrm{eV}$. These binding energies are very similar to neutral reference bismuth(III) halide compounds $\mathrm{BiF}_{3} \mathrm{Bi}_{4 \mathrm{f}_{7 / 2}}=161.0 \mathrm{eV}$ and $\mathrm{Bi}_{3} \mathrm{Bi}_{4 \mathrm{f}_{7 / 2}=}=$ $159.5 \mathrm{eV} .{ }^{[19]}$ Therefore, for $\left[\mathrm{C}_{4} \mathrm{C}_{1} \mathrm{Im}\right]\left[\mathrm{BiBr}_{3} \mathrm{Cl}\right],\left[\mathrm{C}_{4} \mathrm{C}_{1} \mathrm{Im}\right]\left[\mathrm{BiBr}_{4}\right]$ and $\left[\mathrm{C}_{4} \mathrm{C}_{1} \mathrm{Im}\right]\left[\mathrm{BiBr}_{3} \mathrm{I}\right]$ only bismuth in an oxidation state of $3+$ is present. For $\left[\mathrm{C}_{4} \mathrm{C}_{1} \mathrm{Im}\right]\left[\mathrm{BiBr}_{4}\right]_{0.67} \mathrm{Br}_{0.33}$, which is a solid at room temperature, four peaks are observed in the $\mathrm{Bi} 4 \mathrm{f}$ region, which corresponds to two electronic environments. The binding energies for the $\mathrm{Bi} 4 \mathrm{f}_{7 / 2}$ peaks are $159.7 \mathrm{eV}$ and $157.1 \mathrm{eV}$, which are due to the ionic liquid and bismuth metal respectively (bismuth metal $4 \mathrm{f}_{7 / 2}$ reference $=157.1 \mathrm{eV}$ ). ${ }^{[19]} \mathrm{It}$ is very likely that the bismuth metal was formed by $\mathrm{X}$-ray damage (or low energy electrons produced by the $\mathrm{X}$-rays). The observation that the binding energies are the same for the $B i 4 f_{7 / 2}$ peak due to $\left[\mathrm{BiBr}_{x} A_{y}\right]^{-}$ demonstrates that changing one ligand on the bismuth centre makes relatively little difference to the electronic environment of the bismuth atom.

Two peaks can be seen in $\mathrm{Br} 3 \mathrm{~d}$ region for all four halobismuthate ionic liquids and also $\left[\mathrm{C}_{8} \mathrm{C}_{1} 1 \mathrm{~m}\right] \mathrm{Br}$, $3 d_{3 / 2}$ and $3 d_{5 / 2}$ (Figure $4 b$ ). These two peaks are due to spin orbit coupling; therefore, for all five ionic liquids studied here there is one $\mathrm{Br}$ electronic environment only. The binding energy for the $\mathrm{Br} 3 \mathrm{~d}_{5 / 2}$ peak is $67.5 \mathrm{eV}$ for $\left[\mathrm{C}_{8} \mathrm{C}_{1} \mathrm{Im}\right] \mathrm{Br}$, the same as recorded within the error of the experiment $( \pm 0.1 \mathrm{eV})$ by Villar-Garcia et al. ${ }^{[18 c]}$ This peak is due to $\mathrm{Br}^{-}$, and can be used as a reference. For all four halobismuthate ionic liquids, the binding energy of the $B r 3 d_{5 / 2}$ peak is $68.8 \pm 0.1 \mathrm{eV}$, i.e. the same, within the error of the experiment $( \pm 0.2 \mathrm{eV})$. The difference in binding energy between the $\mathrm{Br} 3 \mathrm{~d}_{5 / 2}$ 
peak for $\mathrm{Br}^{-}$and the $\mathrm{Br}_{3 / 2}$ peak for the four halobismuthate ionic liquids is $\sim 1.3 \mathrm{eV}$. This difference is far larger than the error of the experiment $( \pm 0.2 \mathrm{eV})$. Therefore, it can be conclusively stated that there is no lone $\mathrm{Br}^{-}$present in any of the four bismuth-containing ionic liquids, demonstrating that all $\mathrm{Br}$ atoms in the halobismuthate ionic liquids are all ligands attached to $\mathrm{Bi}$. For $\left[\mathrm{C}_{4} \mathrm{C}_{1} \mathrm{Im}\right]\left[\mathrm{BiBr}_{4}\right]_{0.67} \mathrm{Br}_{0.33}$, the additional $\mathrm{Br}$ atoms are accommodated as ligands by the $\mathrm{Bi}$. This observation is supported by crystallography, where anionic bismuth complexes are observed with large anions, such as $\left[\mathrm{N}_{1,1,1,1}\right]_{3}\left[\mathrm{Bi}_{2} \mathrm{Cl}_{9}\right]$ and $\left[\mathrm{N}_{1,1,1,1}\right]_{3}\left[\mathrm{Bi}_{2} \mathrm{Br}_{9}\right]$ (where $\left[\mathrm{N}_{1,1,1,1}\right]^{+}=$ tetramethylammonium). ${ }^{[20]}$ In addition, the $\mathrm{Br}$ in the four halobismuthate ionic liquids was significantly more positively charged than $\mathrm{Br}^{-}$. The $\mathrm{Br}^{-}$anion has a charge of a little less than -1 e due to charge donation to the cation; from calculations on ion pairs, -0.8 e has been determined. ${ }^{[21]}$ This is to be expected given the Lewis acidity of $\mathrm{Bi}^{3+}$. The charge of the $\mathrm{Br}$ atoms in the halobismuthate ionic liquids will be closer to 0 e than for $\mathrm{Br}^{-}$. The observation that the $\mathrm{Br}_{3} \mathrm{~d}_{5 / 2}$ peak due to $\left[\mathrm{BiBr}_{x} \mathrm{~A}_{y}\right]^{-}$ is the same demonstrates that changing one ligand on the bismuth centre makes relatively little difference to the charge on the $\mathrm{Br}^{-}$ligands.

For the $\mathrm{Cl} 2 \mathrm{p}$ region for $\left[\mathrm{C}_{4} \mathrm{C}_{1} 1 \mathrm{~m}\right]\left[\mathrm{BiBr}_{3} \mathrm{Cl}\right]$, two $\mathrm{Cl}$ peaks are observed, due to spin orbit coupling (Figure S15). Therefore, there is one $\mathrm{Cl}$ electronic environment for $\left[\mathrm{C}_{4} \mathrm{C}_{1} \mathrm{Im}\right]\left[\mathrm{BiBr}_{3} \mathrm{Cl}\right]$. The $\mathrm{Cl} 2 \mathrm{p}_{3 / 2}$ binding energy for $\left[C_{4} C_{1} I m\right]\left[B i B r_{3} C l\right]$ is $198.5 \mathrm{eV}$. The $\mathrm{Cl} 2 \mathrm{p}_{3 / 2}$ binding energy for $\left[\mathrm{C}_{8} \mathrm{C}_{1} \mathrm{Im}\right] \mathrm{Cl}$ is 197.1 $\mathrm{eV}{ }^{[18 \mathrm{c}]}$ Therefore, there is no free $\mathrm{Cl}^{-}$present in $\left[\mathrm{C}_{4} \mathrm{C}_{1} \mathrm{Im}\right]\left[\mathrm{BiBr}_{3} \mathrm{Cl}\right]$. In addition, $\mathrm{Cl}$ in $\left[\mathrm{C}_{4} \mathrm{C}_{1} \mathrm{Im}\right]\left[\mathrm{BiBr}_{3} \mathrm{Cl}\right]$ is more positively charged than in $\left[C_{8} C_{1} I m\right] C l$. For the I $3 \mathrm{~d}$ region for $\left[C_{4} C_{1} I m\right]\left[B_{B} r_{3} I\right]$, two I peaks are observed, due to spin orbit coupling (Figure S17). Therefore, there is one I electronic environment for $\left[C_{4} C_{1} I m\right]\left[B i B r_{3} I\right]$. The I $3 d_{5 / 2}$ binding energy for $\left[C_{4} C_{1} I m\right]\left[B i B r_{3} I\right]$ is $619.5 \mathrm{eV}$. The I $3 d_{5 / 2}$ binding energy for $\left[C_{8} C_{1} I m\right] I$ is $618.5 \mathrm{eV} .{ }^{[18 c]}$ Therefore, there is no free $I^{-}$present for $\left[C_{4} C_{1} I m\right]\left[B_{B B r} I\right]$. In addition, I in $\left[C_{4} C_{1} I m\right]\left[B i B r_{3} I\right]$ is more positively charged than in $\left[C_{8} C_{1} I m\right] l$.

For all five ionic liquids studied here, only one nitrogen peak is observed (Figures S15-S19), as expected for $\left[\mathrm{C}_{n} \mathrm{C}_{1} I \mathrm{~m}\right]^{+}$, as the two nitrogen atoms are indistinguishable by XPS. ${ }^{[17]}$ For the three halobismuthate compounds that are liquid at room temperature, $\mathrm{N}_{\text {cation }} 1 \mathrm{~s}$ is $401.9 \mathrm{eV}$. Due to the relatively large error for the halobismuthate ionic liquids $( \pm 0.2 \mathrm{eV})$, the binding energies, whilst all intermediate between $\mathrm{N}_{\text {cation }} 1 \mathrm{~s}$ for $\left[\mathrm{C}_{8} \mathrm{C}_{1} 1 \mathrm{~m}\right]\left[\mathrm{Tf}_{2} \mathrm{~N}\right]$ and $\left[\mathrm{C}_{8} \mathrm{C}_{1} \mathrm{Im}\right] \mathrm{Br}$, cannot be distinguished.

\subsection{Speciation}

Due to the labile nature of the bismuth-halogen bond, it is expected that a number of different anionic species might form in bismuth halometallates, as with haloaluminates. ${ }^{[7]}$

Mass spectra (section 2.1) indicate that when more than one halide element is present, the ligands are randomly distributed amongst the bismuth ions. That is to say, when chloride and bromide are both present, all possible ligand combinations are found (e.g. $\left[\mathrm{BiBr}_{4}\right]^{-},\left[\mathrm{BiClBr}_{3}\right]^{-},\left[\mathrm{BiCl}_{2} \mathrm{Br}_{2}\right]^{-}$etc.). The existence of mixed halide dialkylimidazolium haloaluminates, specifically $\left[\mathrm{AlBrCl}_{3}\right]^{-}$and $\left[\mathrm{AlCl}_{3}\right]^{-}$, has previously been reported by Koronais and Osteryoung. ${ }^{[22]}$ Based on the MALDI ${ }^{-} \mathrm{m} / z$ peak intensities, the most common complex in both $\left[\mathrm{C}_{4} \mathrm{C}_{1} I \mathrm{~m}\right]\left[\mathrm{BiBr}_{3} \mathrm{Cl}\right]$ and $\left[\mathrm{C}_{4} \mathrm{C}_{1} \mathrm{Im}\right]\left[\mathrm{BiBr}_{3} \mathrm{I}\right]$ is not the stoichiometric ratio of ions (i.e. $\left[\mathrm{BiBr}_{3} \mathrm{Cl}\right]^{-}$or $\left[\mathrm{BiBr}_{3}\right]^{-}$) but $\left[\mathrm{BiBr}_{4}\right]^{-}$. This suggests that there might be a preference for the ions to disproportionate, forming $\left[\mathrm{BiBr}_{4}\right]^{-}$and $\left[\mathrm{BiBr}_{2} \mathrm{Cl}_{2}\right]^{-}$rather than two $\left[\mathrm{BiBr}_{3} \mathrm{Cl}\right]^{-}$ions.

The presence of uncoordinated halide ions is unclear based on the available results. Peaks for uncoordinated halide ions $\left(\mathrm{Br}^{-}\right.$and $\mathrm{I}^{-}$) were present in the $\mathrm{LSIMS}^{-}$mass spectra, although these may 
predominantly have been the result of fragmentation of complex ions upon ionisation. XP measurements only detected the presence of one environment for $\mathrm{Cl}, \mathrm{Br}$ and $\mathrm{I}$, and the binding energies were different to those of free ions measured in bismuth-free reference compounds. Even when excess $\mathrm{Br}^{-}$was present in the compound $\left[\mathrm{C}_{4} \mathrm{C}_{1} \mathrm{Im}\right]\left[\mathrm{BiBr}_{4}\right]_{0.67} \mathrm{Br}_{0.33}$, only one $\mathrm{Br}$ environment was observed suggesting that the extra ions were bound to the bismuth ions. On the other hand, because $T_{\text {onset }}$ for $\left[\mathrm{C}_{4} \mathrm{C}_{1} \mathrm{Im}\right]\left[\mathrm{BiCl}_{4}\right]$ was close to $T_{\text {onset }}\left[\mathrm{C}_{4} \mathrm{C}_{1} \mathrm{Im}\right] \mathrm{Cl}$ (see section 2.3), the chloride ligands in the $\left[\mathrm{BiCl}_{4}\right]^{-}$anion may be more labile and free to attack the dialkylimidazolium cation than in the other halobismuthate analogues. This is in contrast to $\left[\mathrm{C}_{4} \mathrm{C}_{1} \mathrm{Im}\right]\left[\mathrm{BiBr}_{4}\right]$ which has a $T_{\text {onset }}$ of $380{ }^{\circ} \mathrm{C}$; much higher than the $T_{\text {onset }}$ of $273{ }^{\circ} \mathrm{C}$ for $\left[\mathrm{C}_{4} \mathrm{C}_{1} \mathrm{Im}\right] \mathrm{Br} .{ }^{[23]}$ Furthermore, since iodide is more nucleophilic than chloride and bromide, and based on the results of Chan et al. demonstrating the thermolysis of $\left[\mathrm{C}_{4} \mathrm{C}_{1} \mathrm{Im}\right] \mathrm{I}$ at $220{ }^{\circ} \mathrm{C}$ to $260{ }^{\circ} \mathrm{C}$, the $T_{\text {onset }}$ of $\left[\mathrm{C}_{4} \mathrm{C}_{1} \mathrm{Im}\right] \mathrm{l}$ should be expected to be similar (no higher) than that of $\left[\mathrm{C}_{4} \mathrm{C}_{1} \mathrm{Im}\right] \mathrm{Cl}$ or $\left[\mathrm{C}_{4} \mathrm{C}_{1} 1 \mathrm{~m}\right] \mathrm{Br} .{ }^{[24]}$ Given that the $T_{\text {onset }}$ of $\left[\mathrm{C}_{4} \mathrm{C}_{1} \mid \mathrm{m}\right]\left[\mathrm{BiBr}_{3} \mid\right]$ is $372{ }^{\circ} \mathrm{C}$, the iodide ion appears to be strongly bound to the bismuth centre.

When the ratio of bismuth halide to dialkylimidazolium is 2:1 (i.e. $\left[\mathrm{C}_{4} \mathrm{C}_{1} 1 \mathrm{~m}\right]\left[\mathrm{Bi}_{2} \mathrm{Br}_{7}\right]$ and $\left.\left[\mathrm{C}_{4} \mathrm{C}_{1} \mathrm{Im}\right]\left[\mathrm{Bi}_{2} \mathrm{Brl}_{6}\right]\right)$, LSIMS ${ }^{-}$peaks for bismuth dimers (e.g. $\left[\mathrm{Bi}_{2} \mathrm{Br}_{3}\right]^{-}$and $\left[\mathrm{Bi}_{2} I_{3}\right]^{-}$) and even trimers $\left(\left[\mathrm{Bi}_{3} \mathrm{Br}_{6} \mathrm{I}_{3}\right]^{-}\right)$are seen. The relative abundance of these peaks is low (2\% to 5\%) while monomeric species still dominate. It is unclear whether this is because the dimers readily fragment upon ionisation or whether their relative abundance in the liquid is similarly low. XP spectra only detect the presence of one bismuth environment and are not able to distinguish the presence of differently coordinated bismuth centres or bismuth dimers in a single liquid.

\section{Experimental}

\subsection{Synthesis of halobismuthate compounds}

All ionic liquids were prepared in approximately $10 \mathrm{~g}$ quantities by mixing a dialkylimidazolium halide salt with a bismuth halide salt in the desired molar ratio. The halide ion from the imidazolium salt transferred onto the bismuth salt to form the halobismuthate ion. The reagents were stirred under vacuum ( $<10^{-1} \mathrm{mbar}$ ) at $100{ }^{\circ} \mathrm{C}$ until a homogeneous liquid had formed (5-30 min). For example: Dry $\left[\mathrm{C}_{4} \mathrm{C}_{1} \mathrm{Im}\right] \mathrm{Cl}(2.92 \mathrm{~g}, 167 \mathrm{mmol})$ was added to $\mathrm{BiBr}_{3}(7.50 \mathrm{~g}, 167 \mathrm{mmol})$ and stirred under vacuum at $100{ }^{\circ} \mathrm{C}$ for $30 \mathrm{~min}$ yielding a homogenous and transparent yellow liquid (10.42 g). Mixtures with $\left[\mathrm{C}_{4} \mathrm{C}_{1} \mathrm{Im}\right]\left[\mathrm{NTf}_{2}\right]$ were prepared by mixing $\left[\mathrm{C}_{4} \mathrm{C}_{1} \mathrm{Im}\right]\left[\mathrm{NTf}_{2}\right]$ with a pre-prepared imidazolium halobismuthate liquid in a 50:50 mol\% ratio. $\left[\mathrm{C}_{4} \mathrm{C}_{1} \mathrm{Im}\right][\mathrm{Cl}]\left(\geq 98.0 \%\right.$, Aldrich), $\left[\mathrm{C}_{4} \mathrm{C}_{1} \mathrm{Im}\right][\mathrm{Br}](>97.0 \%$, Fluka), $\left[\mathrm{C}_{2} \mathrm{C}_{1} \mathrm{Im}\right][\mathrm{Cl}]$ (98\%, Aldrich), $\left[\mathrm{C}_{4} \mathrm{C}_{1} \mathrm{Im}\right]\left[\mathrm{NTf} \mathrm{f}_{2}\right](\geq 98.0 \%, \mathrm{BASF}), \mathrm{BiCl}_{3}\left(\geq 98 \%\right.$, Aldrich), $\mathrm{BiBr}_{3}(\geq 98 \%$, Aldrich) and $\mathrm{Bil}_{3}\left(99.999 \%\right.$, Alfa Aesar) were dried under vacuum at $50{ }^{\circ} \mathrm{C}$ for several hours before use. The samples were stored in a vacuum dessicator prior to further study.

\subsection{Density}

Density measurements were made gravimetrically using a $1 \mathrm{ml}$ volumetric flask calibrated against ultrapure water.

\subsection{Viscosity}


Steady shear rheology experiments were performed on a stress-controlled shear rheometer (T.A. Instruments, model AR-G2), with a $40 \mathrm{~mm}$ diameter cone-plate with angle $2^{\circ} 0^{\prime} 11^{\prime \prime}$ and a gap of $52 \mu \mathrm{m}$. The viscosity was measured over a range of temperatures, controlled by the inbuilt Peltier plate.

\subsection{Mass spectrometry}

ESI mass spectrometry was performed on a Waters 'LCT Premier' mass spectrometer. LSIMS mass spectrometry was performed on a 'Micromass AutoSpec Premier' mass spectrometer. MALDI mass spectrometry was performed on a Micromass 'MALDI-ToF' mass spectrometer.

\subsection{NMR spectroscopy}

NMR spectra were recorded on Bruker Avance-400 $\left({ }^{1} \mathrm{H}(400 \mathrm{MHz}),{ }^{13} \mathrm{C}(100 \mathrm{MHz})\right)$ NMR spectrometers. Chemical shifts are reported in ppm (relative to the DMSO-d6 residual peak).

\subsection{Thermo gravimetric analysis (TGA)}

TGA spectra were obtained on a PerkinElmer 'Pyris 1 TGA' Thermogravimetric Analyzer, using platinum sample pans of $6 \mathrm{~mm}$ diameter. Temperature-ramped TGA experiments were carried out for ionic liquids in the range of $80{ }^{\circ} \mathrm{C}$ to $700{ }^{\circ} \mathrm{C}$. Between $5 \mathrm{mg}$ and $15 \mathrm{mg}$ of the ionic liquid was measured into the platinum pan. A drying procedure was implemented: the ionic liquid was heated to $80^{\circ} \mathrm{C}$ for 30 minutes in the TGA apparatus, in order to remove water. The drying procedure was justified since the onset decomposition temperature of each compound is substantially higher (at least $180^{\circ} \mathrm{C}$ ) than the $80^{\circ} \mathrm{C}$ drying temperature, and the drying period is short. Therefore, actual decomposition of each ionic liquid during the drying period will be negligible. A ramping rate of $10{ }^{\circ} \mathrm{C}$ $\mathrm{min}^{-1}$ and a nitrogen flow of $20 \mathrm{ml} \mathrm{min}{ }^{-1}$ were used for all temperature-ramped experiments.

\subsection{Water content}

Water content was measured using a Mettler Toledo V20 Volumetric Karl Fischer Titrator.

\subsection{XPS}

XPS was carried out using a Thermo K-alpha spectrometer utilising Al Ka radiation (1486.6 eV) and a quartz crystal monochromator set in a $250 \mathrm{~mm}$ Rowland circle. The X-ray spot was focussed at the sample to a size of $400 \mu \mathrm{m}$. The base pressure was $10^{-9} \mathrm{mbar}$, and the analyser was a double focusing $180^{\circ}$ hemisphere with mean radius $125 \mathrm{~mm}$ which was run in constant analyser energy mode. The pass energy was set to $200 \mathrm{eV}$ for survey scans and $20 \mathrm{eV}$ for high resolution regions. The detector was a 128 channel position sensitive detector. The energy scale of the instrument was regularly calibrated using a three point $(\mathrm{Cu}, \mathrm{Ag}, \mathrm{Au})$ scale. Drops of the samples were placed directly onto a stainless steel plate. These were placed in a loadlock and the pressure reduced to $10^{-7} \mathrm{mbar}$ by pumping down overnight if necessary. There was no significant outgassing or boiling of the samples during this process. After attaining the required pressure, samples were transferred to the analysis chamber. Where necessary, etching was carried out using a $500 \mathrm{eV}$ Ar ion gun. Charge compensation was achieved using a dual beam flood gun which applies both electrons and low energy $\mathrm{Ar}^{+}$ions to the sample. 


\section{Conclusions}

Ionic liquids containing bismuth-centred halometallate anions have been synthesised as confirmed by NMR Spectroscopy, Electrospray Ionisation Mass Spectrometry, Liquid Secondary Ion Mass Spectrometry, Matrix-assisted Laser Desorption/Ionization Mass Spectrometry and XPS. Mass Spectrometry data indicated the existence of both monomeric and dimeric bismuth complexes, while XP spectra were able to identify one environment for $\mathrm{Bi}, \mathrm{Cl}, \mathrm{Br}$ and $\mathrm{I}$. When more than one halide species was present in the liquid, the halide ions appeared to be distributed randomly between bismuth ion centres, resulting in the formation of many different anionic complexes.

The dialkylimidazolium halobismuthates have the highest densities yet reported for ionic liquids, due to the high molecular mass of bismuth and the complexed $\mathrm{Br}^{-}$and $\mathrm{I}^{-}$ions. The liquids have high viscosities but can be mixed with low viscosity $\left[\mathrm{C}_{4} \mathrm{C}_{1} I \mathrm{~m}\right]\left[\mathrm{NTf}_{2}\right]$, bringing about a dramatic reduction in viscosity. Furthermore, viscosity decreased rapidly upon heating. The majority of halobismuthate ionic liquids were shown to exhibit excellent thermal stability with $T_{\text {onset }}$ decomposition temperatures upwards of $370^{\circ} \mathrm{C}$.

Given that bismuth is used extensively in synthetic chemistry, as are haloaluminates, it is likely that halobismuthate ionic liquids could be used in synthetic applications. ${ }^{[6,25]}$ The room temperature electrochemical deposition of bismuth may also be possible. Various engineering applications are envisaged for these liquids in light of their combination of very high density, chemical stability, stability at elevated temperatures, low volatility, and moderate viscosity.

\section{$\underline{5 \text { Acknowledgements }}$}

This work was supported by the Leverhulme Trust (F/07 134/DK and F/07 134/ DN), the John Fell Fund (Oxford University) and The Office of Naval Research (N00014-10-1-0096). Paola Ferrari and Prof. Dirk Aarts are thanked for their help with viscosity measurements. The authors are grateful to Prof. Tom Welton of Imperial College, London, for use of the NMR, Mass Spectrometry, Thermogravimetric Analysis and Karl Fischer apparatus.

\section{$\underline{\text { Figures }}$}

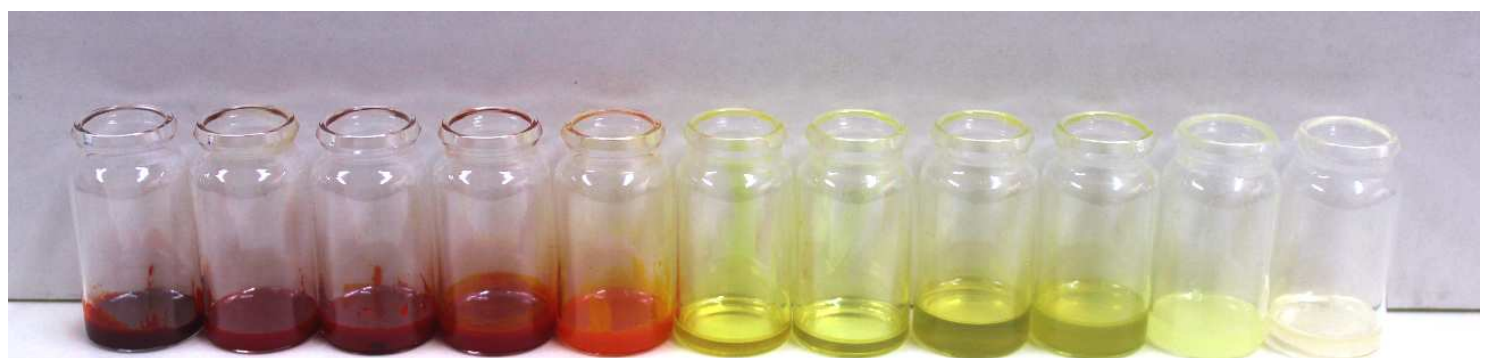

Figure 1. $\left[\mathrm{C}_{4} \mathrm{C}_{1} \mathrm{Im}\right]^{+}$based halobismuthate ionic liquids with different anions (from left to right): $\left[\mathrm{Bil}_{3} \mathrm{Br}\right]^{-},\left[\mathrm{Bil}_{3} \mathrm{Cl}\right]^{-},\left[\mathrm{BiBr}_{2} \mathrm{I}_{2}\right]^{-},\left[\mathrm{BiCl}_{2} \mathrm{I}_{2}\right]^{-},\left[\mathrm{BiBr}_{2} \mathrm{ClI}\right]^{-},\left[\mathrm{BiBr}_{4}\right]^{-},\left[\mathrm{BiBr}_{3} \mathrm{Cl}\right]^{-},\left[\mathrm{BiBr}_{3} \mathrm{Cl}\right]^{-}{ }_{0.5}\left[\mathrm{NTf}_{2}\right]_{0.5}^{-},\left[\mathrm{BiBr}_{2} \mathrm{Cl}_{2}\right]^{-}$, $[\mathrm{BiBrCl}]_{3}^{-},\left[\mathrm{BiCl}_{4}\right]^{-}$. 


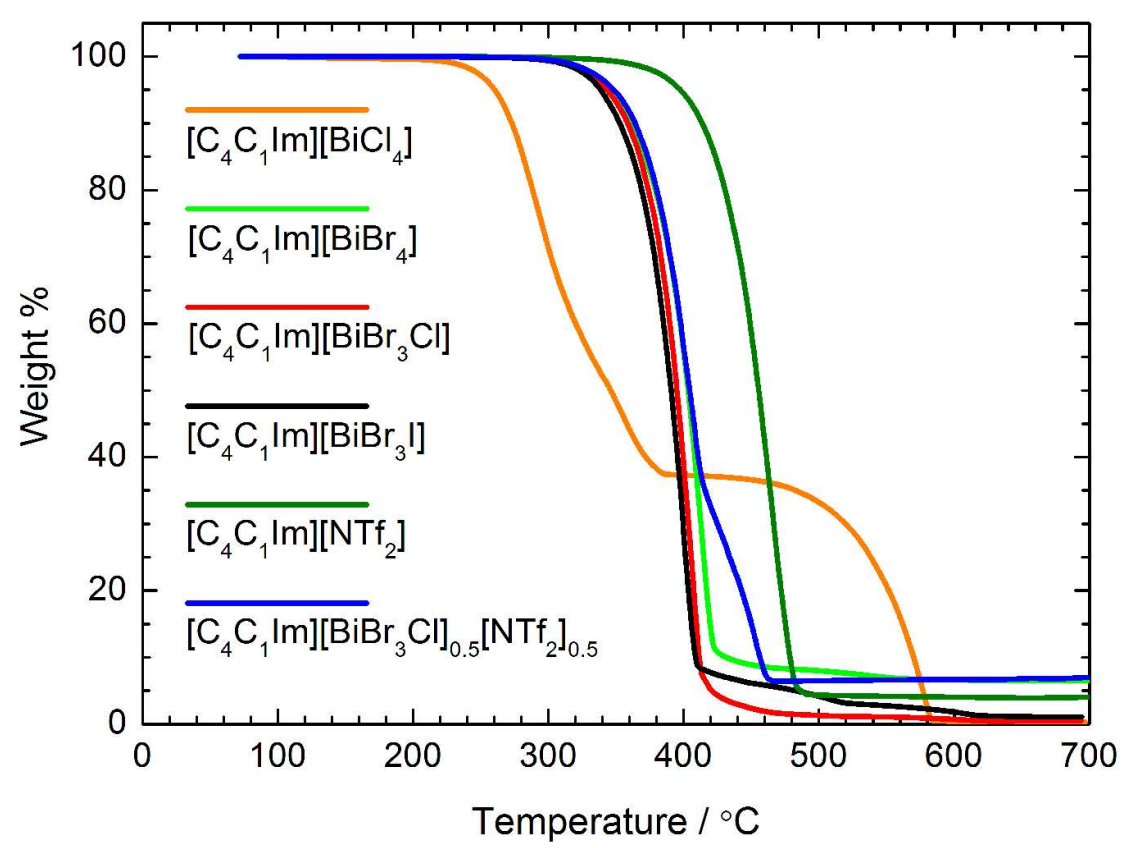

Figure 2. Temperature-ramped TGA thermographs of halobismuthate liquids, $\left[\mathrm{C}_{4} \mathrm{C}_{1} \operatorname{lm}\right]\left[\mathrm{NTf}_{2}\right]$, and the mixture $\left[\mathrm{C}_{4} \mathrm{C}_{1} \mathrm{Im}\right]\left[\mathrm{BiBr}_{3} \mathrm{Cl}\right]_{0.5}\left[\mathrm{NTf}_{2}\right]_{0.5}$, measured with a heating rate of $10{ }^{\circ} \mathrm{C} \mathrm{min}{ }^{-1}$. As the temperature of the liquids is increased, the mass loss from evaporation of decomposition products is recorded simultaneously.

a)

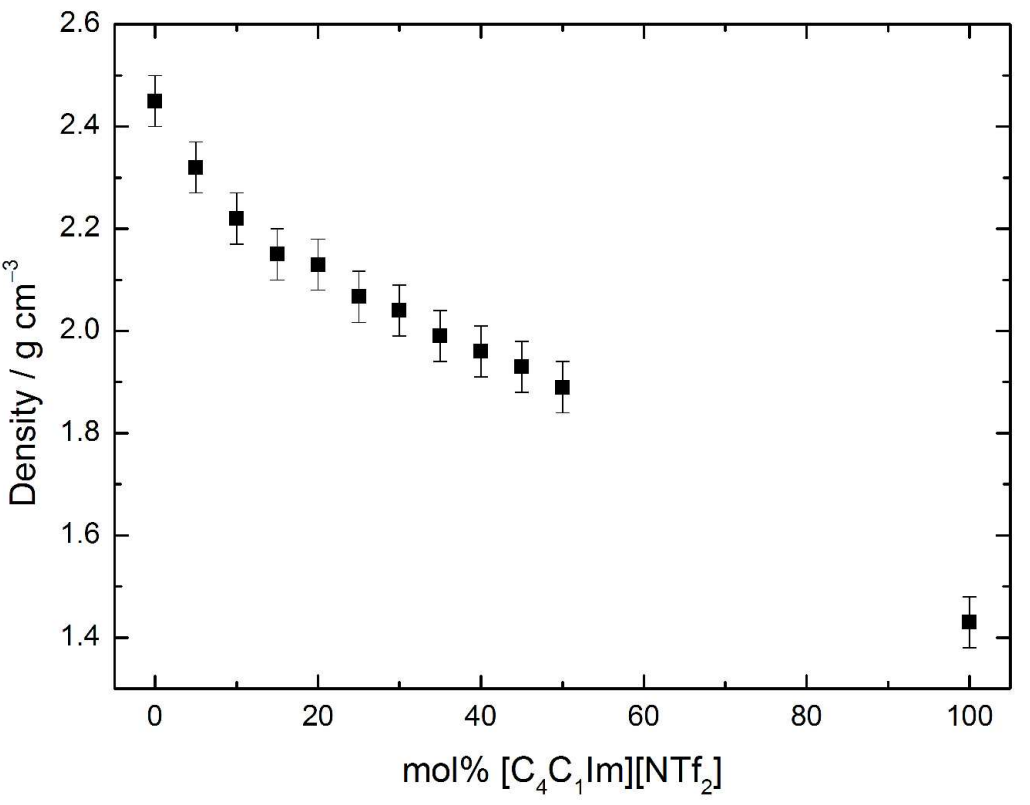




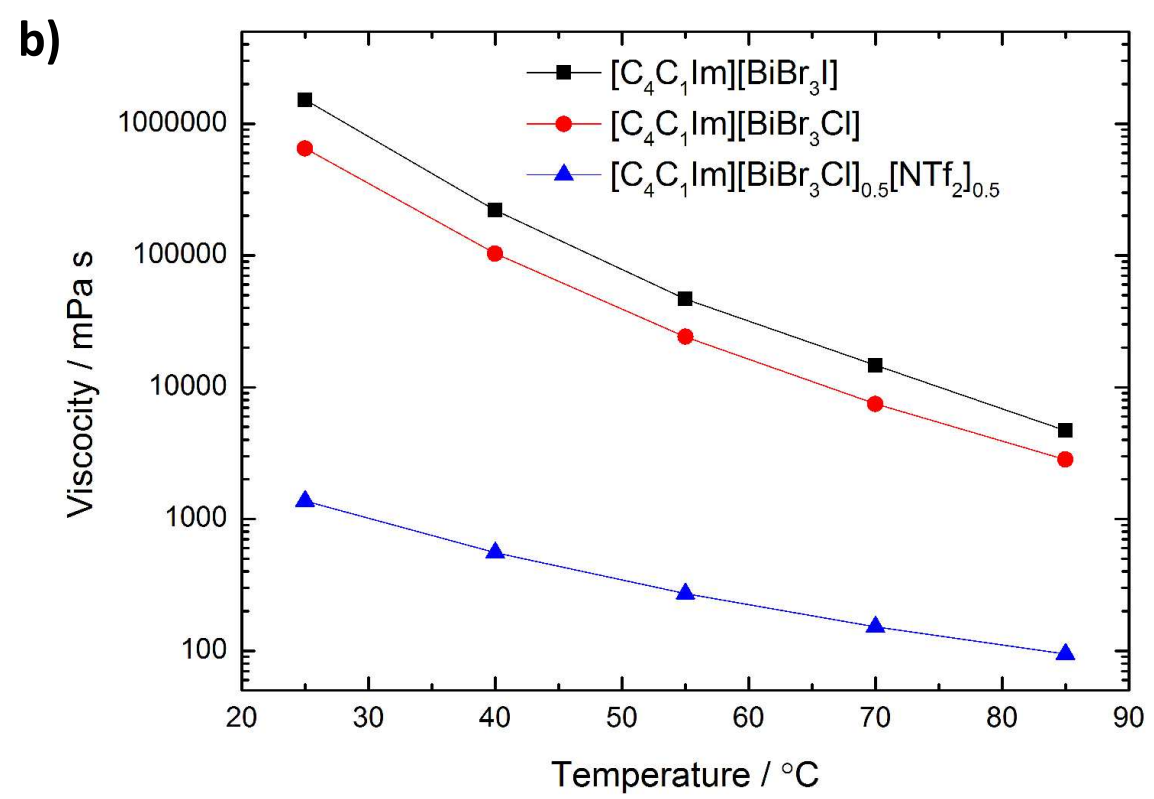

Figure 3. a) Density of $\left[\mathrm{C}_{4} \mathrm{C}_{1} \mid \mathrm{m}\right]\left[\mathrm{BiBr}_{3} \mathrm{Cl}\right] /\left[\mathrm{C}_{4} \mathrm{C}_{1} \mid \mathrm{m}\right]\left[\mathrm{NTf} \mathrm{f}_{2}\right]$ mixtures with varying $\left[\mathrm{C}_{4} \mathrm{C}_{1} \mid \mathrm{m}\right]\left[\mathrm{NTf} \mathrm{f}_{2}\right]$ concentration. b) Viscosity of $\left[\mathrm{C}_{4} \mathrm{C}_{1} \mathrm{Im}\right]\left[\mathrm{BiBr}_{3} \mathrm{Cl}\right],\left[\mathrm{C}_{4} \mathrm{C}_{1} \mathrm{Im}\right]\left[\mathrm{BiBr}_{3} \mathrm{l}\right]$ and $\left[\mathrm{C}_{4} \mathrm{C}_{1} \mathrm{Im}\right]\left[\mathrm{BiBr}_{3} \mathrm{Cl}_{0.5}\left[\mathrm{NTf}_{2}\right]_{0.5}\right.$ between $25^{\circ} \mathrm{C}$ and $85^{\circ} \mathrm{C}$. Error bars of $\pm 5 \%$ are not visible. 

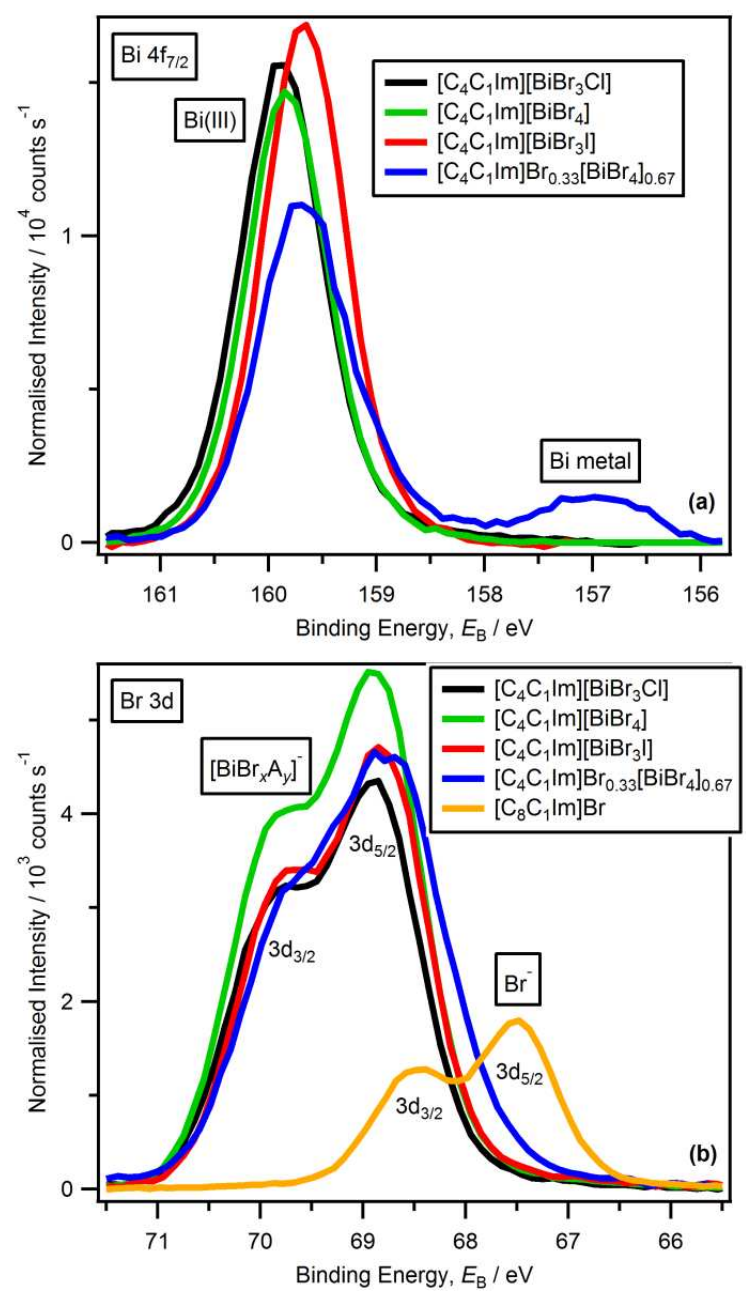

Figure 4. $X P$ spectra for the four bismuth-containing ionic liquids $\left(\left[\mathrm{C}_{4} \mathrm{C}_{1} \mathrm{Im}\right]\left[\mathrm{BiBr}_{3} \mathrm{Cl}\right],\left[\mathrm{C}_{4} \mathrm{C}_{1} \mid \mathrm{m}\right]\left[\mathrm{BiBr}_{4}\right]\right.$, $\left[\mathrm{C}_{4} \mathrm{C}_{1} \mathrm{Im}\right]\left[\mathrm{BiBr}_{3} \mathrm{I}\right]$, and $\left.\left[\mathrm{C}_{4} \mathrm{C}_{1} \mathrm{Im}\right]\left[\mathrm{BiBr}_{4}\right]_{0.67} \mathrm{Br}_{0.33}\right)$ and $\left[\mathrm{C}_{8} \mathrm{C}_{1} \mathrm{Im}\right] \mathrm{Br}$ : (a) $\mathrm{Bi} 4 \mathrm{f}_{7 / 2}$, (b) $\mathrm{Br} 3 \mathrm{~d}$. The experimental values are derived from XP spectra taken at $\theta=0^{\circ}$. XP spectra were charge corrected by referencing $\mathrm{C}_{\text {alkyl }} 1 \mathrm{~s}$ to $285.0 \mathrm{eV}$. To aid visual interpretation of the XP spectra presented here, all XP spectra are normalised to the fitted area of $\mathrm{N}_{\text {cation }} 1 \mathrm{~s}$, the peak due to the nitrogen atoms in the imidazolium ring. 


\section{$\underline{\text { Tables }}$}

\begin{tabular}{|c|c|c|c|}
\hline Ionic Liquid & Density $\pm 0.05 / \mathrm{g} \mathrm{cm}^{-3}$ & Viscosity $\pm 5 \% / \mathrm{Pa}$ s @ $25^{\circ} \mathrm{C}$ & Glass transition $/{ }^{\circ} \mathrm{C}$ \\
\hline$\left[\mathrm{C}_{2} \mathrm{C}_{1} \mathrm{Im}\right]\left[\mathrm{BiBr}_{3} \mathrm{Cl}\right]$ & $2.62 *$ & & $<50$ \\
\hline$\left[\mathrm{C}_{4} \mathrm{C}_{1} \mathrm{Im}\right]\left[\mathrm{BiBr}_{3} \mathrm{Cl}\right]$ & 2.41 & 648 & $<25$ \\
\hline$\left[\mathrm{C}_{4} \mathrm{C}_{1} \mathrm{Im}\right]\left[\mathrm{BiBr}_{4}\right]$ & 2.49 & & $<25$ \\
\hline$\left[\mathrm{C}_{4} \mathrm{C}_{1} \mathrm{Im}\right]\left[\mathrm{BiBr}_{3} \mathrm{Cl}\right]\left[\mathrm{BiBr}_{3}\right]_{0.5}$ & 2.65 & & $<25$ \\
\hline$\left[\mathrm{C}_{4} \mathrm{C}_{1} \mathrm{~lm}\right]\left[\mathrm{Bi}_{2} \mathrm{Br}_{6} \mathrm{Cl}\right]$ & 2.92 & & $<50$ \\
\hline$\left[\mathrm{C}_{4} \mathrm{C}_{1} \mathrm{Im}\right]\left[\mathrm{BiBr}_{3} \mathrm{Cl}\right]_{0.5}\left[\mathrm{NTf}_{2}\right]_{0.5}$ & 1.89 & 1.370 & $<25$ \\
\hline$\left[\mathrm{C}_{4} \mathrm{C}_{1} \mathrm{Im}\right]\left[\mathrm{BiBr}_{3} \mathrm{I}\right]$ & 2.63 & 1517 & $<25$ \\
\hline$\left[\mathrm{C}_{4} \mathrm{C}_{1} \mathrm{Im}\right]\left[\mathrm{BiBr}_{3}\right]$ & 2.78 & & $<50$ \\
\hline$\left[\mathrm{C}_{4} \mathrm{C}_{1} \mathrm{Im}\right]\left[\mathrm{Bi}_{2} \mathrm{Brl}_{6}\right]$ & $3.43^{* *}$ & & $<100$ \\
\hline
\end{tabular}

${ }^{*}$ measured at $50^{\circ} \mathrm{C}$

$* *$ measured at $100^{\circ} \mathrm{C}$

Table 1. Densities, viscosities and upper bound of glass transition temperature of a range of halobismuthate ionic liquids.

\begin{tabular}{ll}
\hline Ionic Liquid & $T_{\text {onset }} /{ }^{\circ} \mathrm{C}$ \\
\hline$\left[\mathrm{C}_{4} \mathrm{C}_{1} \mathrm{Im}\right]\left[\mathrm{NTf}_{2}\right]$ & 425 \\
{$\left[\mathrm{C}_{4} \mathrm{C}_{1} \mathrm{Im}\right]\left[\mathrm{BiCl}_{4}\right]$} & 260 \\
{$\left[\mathrm{C}_{4} \mathrm{C}_{1} \mathrm{Im}\right]\left[\mathrm{BiBr}_{3} \mathrm{Cl}\right]$} & 375 \\
{$\left[\mathrm{C}_{4} \mathrm{C}_{1} \mathrm{Im}\right]\left[\mathrm{BiBr}_{4}\right]$} & 380 \\
{$\left[\mathrm{C}_{4} \mathrm{C}_{1} \mathrm{Im}\right]\left[\mathrm{BiBr}_{3} \mid\right]$} & 372 \\
{$\left[\mathrm{C}_{4} \mathrm{C}_{1} \mathrm{~m}\right]\left[\mathrm{BiBr}_{3} \mathrm{Cl}\right]_{0.5}\left[\mathrm{NTf}_{2}\right]_{0.5}$} & 370 \\
\hline
\end{tabular}

Table 2. Thermal decomposition temperatures, $T_{\text {onset, }}$ for a range of halobismuthate ionic liquids. 


\begin{tabular}{|c|c|c|c|c|c|c|c|c|c|c|}
\hline & & \multicolumn{4}{|l|}{ Cation } & \multicolumn{4}{|l|}{ Anion } & \multirow{2}{*}{$\begin{array}{l}\text { Contamination } \\
\mathrm{Bi}_{\text {metal }} 4 \mathrm{f}_{7 / 2}\end{array}$} \\
\hline & & $C_{N-C-N} 1 s$ & $C_{\text {hetero }} 1 \mathrm{~s}$ & $\mathrm{C}_{\text {alkyl }} 1 \mathrm{~s}$ & $\mathrm{~N}_{\text {cation }} 1 \mathrm{~s}$ & $\mathrm{Cl}_{\text {anion }} 2 \mathrm{p}_{3 / 2}$ & $\mathrm{Br}_{\text {anion }} 3 \mathrm{~d}_{5 / 2}$ & $I_{\text {anion }} 3 d_{5 / 2}$ & $\mathrm{Bi}_{\text {anion }} 4 \mathrm{f}_{7 / 2}$ & \\
\hline & RSF & 0.205 & 0.205 & 0.205 & 0.350 & 0.367 & 0.367 & 5.610 & 4.250 & 4.250 \\
\hline$\left[\mathrm{C}_{4} \mathrm{C}_{1} \mathrm{Im}\right]\left[\mathrm{BiBr}_{3} \mathrm{Cl}\right]$ & Nominal & 1 & 4 & 3 & 2 & 1 & 3 & 0 & 1 & 0 \\
\hline$\left[\mathrm{C}_{4} \mathrm{C}_{1} \mathrm{Im}\right]\left[\mathrm{BiBr}_{3} \mathrm{Cl}\right]$ & Experimental & 1.7 & 3.5 & 3.4 & 2.1 & 1.0 & 2.6 & & 0.8 & \\
\hline$\left[\mathrm{C}_{4} \mathrm{C}_{1} \mathrm{Im}\right]\left[\mathrm{BiBr}_{4}\right]$ & Nominal & 1 & 4 & 3 & 2 & 0 & 4 & 0 & 1 & 0 \\
\hline$\left[\mathrm{C}_{4} \mathrm{C}_{1} \mathrm{Im}\right]\left[\mathrm{BiBr}_{4}\right]$ & Experimental & 1.4 & 3.9 & 3.3 & 2.2 & & 3.5 & & 0.8 & \\
\hline$\left[\mathrm{C}_{4} \mathrm{C}_{1} \mathrm{Im}\right]\left[\mathrm{BiBr}_{3} \mathrm{I}\right]$ & Nominal & 1 & 4 & 3 & 2 & 0 & 3 & 1 & 1 & 0 \\
\hline$\left[\mathrm{C}_{4} \mathrm{C}_{1} \mathrm{Im}\right]\left[\mathrm{BiBr}_{3} \mathrm{I}\right]$ & Experimental & 1.5 & 3.7 & 3.3 & 2.1 & & 2.8 & 0.9 & 0.8 & \\
\hline$\left[\mathrm{C}_{4} \mathrm{C}_{1} \mathrm{Im}\right]\left[\mathrm{BiBr}_{4}\right]_{0.67} \mathrm{Br}_{0.33}$ & Nominal & 1 & 4 & 3 & 2 & 0 & 3 & 0 & 0.67 & 0 \\
\hline$\left[\mathrm{C}_{4} \mathrm{C}_{1} \mathrm{Im}\right]\left[\mathrm{BiBr}_{4}\right]_{0.67} \mathrm{Br}_{0.33}$ & Experimental & 1.3 & 3.4 & 3.8 & 1.8 & & 2.7 & & 0.5 & 0.1 \\
\hline$\left[\mathrm{C}_{8} \mathrm{C}_{1} \mathrm{Im}\right] \mathrm{Br}$ & Nominal & 1 & 4 & 7 & 2 & 0 & 1 & 0 & 0 & 0 \\
\hline$\left[\mathrm{C}_{8} \mathrm{C}_{1} \mathrm{Im}\right] \mathrm{Br}$ & Experimental & 1.3 & 4.0 & 6.9 & 1.9 & & 0.9 & & & \\
\hline
\end{tabular}


Table 3. Quantitative analysis of the XP spectra of $\left.\left[\mathrm{C}_{4} \mathrm{C}_{1} I \mathrm{~m}\right]\left[\mathrm{BiBr}_{3} \mathrm{Cl}\right],\left[\mathrm{C}_{4} \mathrm{C}_{1} I \mathrm{~m}\right]\left[\mathrm{BiBr}_{4}\right],\left[\mathrm{C}_{4} \mathrm{C}_{1} \mid \mathrm{m}\right]\left[\mathrm{BiBr}_{3}\right]\right]$, $\left[\mathrm{C}_{4} \mathrm{C}_{1} \mathrm{Im}\right]\left[\mathrm{BiBr}_{4}\right]_{0.67} \mathrm{Br}_{0.33}$ and $\left[\mathrm{C}_{8} \mathrm{C}_{1} \mathrm{Im}\right] \mathrm{Br}$. The nominal and the experimentally determined composition in number of atoms are given for the various elements constituting the ionic liquids. The experimental values were derived from XP spectra taken at $\theta=0^{\circ}$. The RSFs were taken from ref ${ }^{[14]}$ and ${ }^{[15]}$. $C_{N-C-N}$ refers to the carbon atom at the $C^{2}$ position of the imidazolium ring; $C_{\text {hetero }}$ refers to all other carbon atoms bonded to a heteroatom, in this case nitrogen (i.e. $C^{4}, C^{5}, C^{6}$ and $C^{7}$ ). 


\begin{tabular}{|c|c|c|c|c|c|c|c|c|c|}
\hline \multirow[b]{2}{*}{ Sample } & \multicolumn{4}{|l|}{ Cation } & \multicolumn{4}{|l|}{ Anion } & \multirow{2}{*}{$\begin{array}{l}\text { Contamination } \\
\mathrm{Bi}_{\text {metal }} 4 \mathrm{f}_{7 / 2}\end{array}$} \\
\hline & $c^{2} 1 s$ & $C_{\text {hetero }} 1 \mathrm{~s}$ & $\mathrm{C}_{\text {alkyl }} 1 \mathrm{~s}$ & $\mathrm{~N}_{\text {cation }} 1 \mathrm{~s}$ & $\mathrm{Cl}_{\text {anion }} 2 \mathrm{p}_{3 / 2}$ & $B r_{\text {anion }} 3 d_{5 / 2}$ & $I_{\text {anion }} 3 d_{5 / 2}$ & $\mathrm{Bi}_{\mathrm{Bi}(I I I)} 4 \mathrm{f}_{7 / 2}$ & \\
\hline$\left[\mathrm{C}_{4} \mathrm{C}_{1} \mathrm{Im}\right]\left[\mathrm{BiBr}_{3} \mathrm{Cl}\right]$ & 287.2 & 286.4 & 285.0 & 401.9 & 198.5 & 68.9 & & 159.9 & \\
\hline$\left[\mathrm{C}_{4} \mathrm{C}_{1} \mathrm{Im}\right]\left[\mathrm{BiBr}_{4}\right]$ & 287.4 & 286.4 & 285.0 & 401.9 & & 68.8 & & 159.8 & \\
\hline$\left[\mathrm{C}_{4} \mathrm{C}_{1} \mathrm{Im}\right]\left[\mathrm{BiBr}_{3} \mathrm{I}\right]$ & 287.3 & 286.4 & 285.0 & 401.9 & & 68.8 & 619.5 & 159.7 & \\
\hline$\left[\mathrm{C}_{4} \mathrm{C}_{1} \mathrm{Im}\right]\left[\mathrm{BiBr}_{4}\right]_{0.67} \mathrm{Br}_{0.33}$ & 287.3 & 286.4 & 285.0 & 401.8 & & 68.7 & & 159.7 & 157.1 \\
\hline$\left[\mathrm{C}_{8} \mathrm{C}_{1} \mathrm{~lm}\right] \mathrm{Br}$ & 287.2 & 286.3 & 285.0 & 401.6 & & 67.4 & & & \\
\hline$\left[\mathrm{C}_{8} \mathrm{C}_{1} \mathrm{Im}\right] \mathrm{Cl}\left(\mathrm{ref}^{[18 \mathrm{cc}]}\right)$ & & & 285.0 & 401.7 & 197.1 & & & & \\
\hline$\left[\mathrm{C}_{8} \mathrm{C}_{1} \mathrm{Im}\right] \mathrm{Br}\left(\operatorname{ref}^{[18 c]}\right)$ & & & 285.0 & 401.7 & & 67.5 & & & \\
\hline$\left[\mathrm{C}_{8} \mathrm{C}_{1} \mathrm{Im}\right] \mathrm{I}\left(\mathrm{ref}^{[18 \mathrm{c}]}\right)$ & & & 285.0 & 401.9 & & & 618.5 & & \\
\hline Bi metal $\left(\operatorname{ref}^{[19]}\right)$ & & & & & & & & & 157.1 \\
\hline $\mathrm{BiF}_{3}\left(\operatorname{ref}^{[19]}\right)$ & & & & & & & & 161.0 & \\
\hline $\mathrm{Bil}_{3}\left(\mathrm{ref}^{[19]}\right)$ & & & & & & & & 159.5 & \\
\hline
\end{tabular}


Table 4. Binding energies in eV from the XP spectra of $\left[\mathrm{C}_{4} \mathrm{C}_{1} \mid \mathrm{m}\right]\left[\mathrm{BiBr}_{3} \mathrm{Cl}\right],\left[\mathrm{C}_{4} \mathrm{C}_{1} \mid \mathrm{m}\right]\left[\mathrm{BiBr}_{4}\right]$, $\left[\mathrm{C}_{4} \mathrm{C}_{1} \mathrm{Im}\right]\left[\mathrm{BiBr}_{3} \mathrm{l}\right],\left[\mathrm{C}_{4} \mathrm{C}_{1} \mathrm{Im}\right]\left[\mathrm{BiBr}_{4}\right]_{0.67} \mathrm{Br}_{0.33}$ and $\left[\mathrm{C}_{8} \mathrm{C}_{1} \mathrm{Im}\right] \mathrm{Br}$. The experimentally determined binding energy values are given for the various elements constituting the ionic liquids. The experimental values were derived from XP spectra taken at $\theta=0^{\circ}$. XP spectra were charge corrected by referencing $C_{\text {alkyl }} 1 \mathrm{~s}$ to $285.0 \mathrm{eV}$. For $\left[\mathrm{C}_{4} \mathrm{C}_{1} \mid \mathrm{m}\right]\left[\mathrm{BiBr}_{3} \mathrm{Cl}\right],\left[\mathrm{C}_{4} \mathrm{C}_{1} \mid \mathrm{m}\right]\left[\mathrm{BiBr}_{4}\right],\left[\mathrm{C}_{4} \mathrm{C}_{1} \mid \mathrm{m}\right]\left[\mathrm{BiBr}_{3} \mid\right]$ and $\left[\mathrm{C}_{4} \mathrm{C}_{1} \mathrm{Im}\right]\left[\mathrm{BiBr}_{4}\right]_{0.67} \mathrm{Br}_{0.33}$, the error was $\pm 0.2 \mathrm{eV}$; for $\left[\mathrm{C}_{8} \mathrm{C}_{1} 1 \mathrm{~m}\right] \mathrm{Br}$, the error was $\pm 0.1 \mathrm{eV}$.

\section{$\underline{\text { References }}$}

[1] M. Galiński, A. Lewandowski and I. Stępniak, lonic liquids as electrolytes, Electrochim. Acta 2006, 51, 5567-5580.

[2] a) S. Hayashi and H. O. Hamaguchi, Discovery of a magnetic ionic liquid [bmim] $\mathrm{FeCl}_{4}, \mathrm{Chem}_{\text {. Lett. }}$ 2004, 33, 1590-1591; b) Y. Yoshida and G. Saito, Progress in Paramagnetic lonic Liquids, Ionic Liquids: Theory, Properties, New Approaches, InTech, 2011, p; c) S. P. Wicelinski, R. J. Gale and J. S. Wilkes, Low Temperature Chlorogallate Molten Salt Systems, J. Electrochem. Soc. 1987, 134, 262-263; d) I. J. B. Lin and C. S. Vasam, Metal-containing ionic liquids and ionic liquid crystals based on imidazolium moiety, J. Organomet. Chem. 2005, 690, 3498-3512.

[3] J. Estager, J. D. Holbrey and M. Swadzba-Kwasny, Halometallate ionic liquids - revisited, Chem. Soc. Rev. 2014, 43, 847-886.

[4] J. G. Huddleston, A. E. Visser, W. M. Reichert, H. D. Willauer, G. A. Broker and R. D. Rogers, Characterization and comparison of hydrophilic and hydrophobic room temperature ionic liquids incorporating the imidazolium cation, Green Chem. 2001, 3, 156-164.

[5] a) E. Ahmed, D. Köhler and M. Ruck, Room-Temperature Synthesis of Bismuth Clusters in lonic Liquids and Crystal Growth of Bi5(AlCl4)3, Z. Anorg. Allg. Chem. 2009, 635, 297-300; b) E. Ahmed and M. Ruck, Homo- and heteroatomic polycations of groups 15 and 16. Recent advances in synthesis and isolation using room temperature ionic liquids, Coord. Chem. Rev. 2011, 255, 2892-2903.

[6] N. M. Leonard, L. C. Wieland and R. S. Mohan, Applications of bismuth(III) compounds in organic synthesis, Tetrahedron 2002, 58, 8373-8397.

[7] A. a. K. Abdul-Sada, A. M. Greenway, K. R. Seddon and T. Welton, Upon the existence of $\left[\mathrm{Al}_{3} \mathrm{Cl}_{10}\right]^{-}$ in room temperature chloroaluminate ionic liquids, Org. Mass Spectrom. 1989, 24, 917-918.

[8] P. Wasserscheid and T. Welton, lonic Liquids in Synthesis, Wiley-VCH, Weinheim, 2008, p.

[9] N. Yang and H. Sun, Biocoordination chemistry of bismuth: Recent advances, Coord. Chem. Rev. 2007, 251, 2354-2366.

[10] a) J. A. Boon, J. S. Wilkes and J. A. Lanning in A fundamental electrochemical investigation of bromoaluminate and mixed bromo-aluminate room temperature molten salt systems, Vol. Frank J. Seiler Research Laboratory, 1989; b) Y. Yoshida and G. Saito, Influence of structural variations in 1alkyl-3-methylimidazolium cation and tetrahalogenoferrate(III) anion on the physical properties of the paramagnetic ionic liquids, J. Mater. Chem. 2006, 16, 1254-1262.

[11] a) Krisztian J. Baranyai, Glen B. Deacon, Douglas R. MacFarlane, Jennifer M. Pringle and J. L. Scott, Thermal Degradation of Ionic Liquids at Elevated Temperatures, Aust. J. Chem. 2004, 57; b) M. T. Clough, K. Geyer, P. A. Hunt, J. Mertes and T. Welton, Thermal decomposition of carboxylate ionic liquids: trends and mechanisms, Phys. Chem. Chem. Phys. 2013, 15, 20480-20495; c) T. J. Wooster, K. M. Johanson, K. J. Fraser, D. R. MacFarlane and J. L. Scott, Thermal degradation of cyano containing ionic liquids, Green Chemistry 2006, 8, 691-696.

[12] Handbook of Chemistry and Physics, CRC Press, Boca Raton, FL, USA, 2006, p.

[13] C. A. Angell, N. Byrne and J.-P. Belieres, Parallel Developments in Aprotic and Protic Ionic Liquids: Physical Chemistry and Applications, Acc. Chem. Res. 2007, 40, 1228-1236. 
[14] C. Kolbeck, T. Cremer, K. R. J. Lovelock, N. Paape, P. S. Schulz, P. Wasserscheid, F. Maier and H. P. Steinrück, Influence of Different Anions on the Surface Composition of Ionic Liquids Studied Using ARXPS, J. Phys. Chem. B 2009, 113, 8682-8688.

[15] C. D. Wagner, L. E. Davis, M. V. Zeller, J. A. Taylor, R. H. Raymond and L. H. Gale, Empirical Atomic Sensitivity Factors for Quantitative-Analysis by Electron-Spectroscopy for Chemical-Analysis, Surf. Interface Anal. 1981, 3, 211-225.

[16] a) R. F. Roberts, D. L. Allara, C. A. Pryde, D. N. E. Buchanan and N. D. Hobbins, Mean free path for inelastic scattering of $1.2 \mathrm{kev}$ electrons in thin poly(methylmethacrylate) films, Surf. Interf. Anal. 1980, 2, 5-10; b) S. Tanuma, C. J. Powell and D. R. Penn, Calculations of Electron Inelastic Mean Free Paths, Surf. Interf. Anal. 1991, 17, 911-926.

[17] K. R. J. Lovelock, I. J. Villar-Garcia, F. Maier, H. P. Steinrück and P. Licence, Photoelectron Spectroscopy of Ionic Liquid-Based Interfaces, Chem. Rev. 2010, 110, 5158-5190.

[18] a) T. Cremer, C. Kolbeck, K. R. J. Lovelock, N. Paape, R. Wölfel, P. S. Schulz, P. Wasserscheid, H. Weber, J. Thar, B. Kirchner, F. Maier and H. P. Steinrück, Towards a Molecular Understanding of Cation-Anion Interactions-Probing the Electronic Structure of Imidazolium Ionic Liquids by NMR Spectroscopy, X-ray Photoelectron Spectroscopy and Theoretical Calculations, Chem. Eur. J. 2010, $16,9018-9033 ;$ b) B. B. Hurisso, K. R. J. Lovelock and P. Licence, Amino acid-based ionic liquids: using XPS to probe the electronic environment via binding energies, Phys. Chem. Chem. Phys. 2011, 13, 17737-17748; c) I. J. Villar-Garcia, E. F. Smith, A. W. Taylor, F. L. Qiu, K. R. J. Lovelock, R. G. Jones and $P$. Licence, Charging of ionic liquid surfaces under X-ray irradiation: the measurement of absolute binding energies by XPS, Phys. Chem. Chem. Phys. 2011, 13, 2797-2808.

[19] W. E. Morgan, W. J. Stec and J. R. Vanwazer, Inner-orbital binding-energy shifts of antimony and bismuth compounds, Inorg. Chem. 1973, 12, 953-955.

[20] a) G. Y. Ahlijah and Goldstei.M, The far-infrared and Raman spectra of the tetra-alkylammonium salts of mixed tetrahalogeno-complexes of arsenic(III), antimony(III), and bismuth(III), $\left[\mathrm{R}_{4} \mathrm{~N}\right]\left[\mathrm{MX}_{3} \mathrm{Y}\right], \mathrm{J}$. Chem. Soc. A 1970, 2590-2594; b) A. G. Landers and T. B. Brill, Structure and bonding in chloro- and bromobismuthate(III) clusters $\left(\mathrm{BiX}_{4}^{-}, \mathrm{Bi}_{2} \mathrm{X}_{9}{ }^{3-}, \mathrm{BiX}_{6}{ }^{3-}\right)$ by NQR spectroscopy, Inorg. Chem. 1980, 19, 744749; c) P. K. Rajan, B. Jagadeesh, K. Venu and V. S. S. Sastry, Proton NMR studies of molecular dynamics in $\left[\left(\mathrm{CH}_{3}\right)_{4} \mathrm{~N}_{3} \mathrm{Bi}_{2} \mathrm{X}_{9}(\mathrm{X}=\mathrm{Cl}\right.$ and $\mathrm{Br})$, Solid State Commun. 1996, 100, 535-540.

[21] R. P. Matthews and P. A. Hunt, private communication.

[22] P. Koronaios and R. A. Osteryoung, Buffering of 1-Ethyl-3-methylimidazolium Chloride/Aluminum Chloride Ionic Liquids Using Alkali Metal Bromides and lodides, J. Electrochem. Soc. 2001, 148.

[23] C. P. Fredlake, J. M. Crosthwaite, D. G. Hert, S. Aki and J. F. Brennecke, Thermophysical properties of imidazolium-based ionic liquids, J. Chem. Eng. Data 2004, 49, 954-964.

[24] B. Chan, N. Chang and M. Grimmett, The synthesis and thermolysis of imidazole quaternary salts, Aust. J. Chem. 1977, 30, 2005-2013.

[25] a) J. P. Hallett and T. Welton, Room-Temperature lonic Liquids: Solvents for Synthesis and Catalysis. 2, Chem. Rev. 2011, 111, 3508-3576; b) J. M. Bothwell, S. W. Krabbe and R. S. Mohan, Applications of bismuth(iii) compounds in organic synthesis, Chem. Soc. Rev. 2011, 40, 4649-4707. 